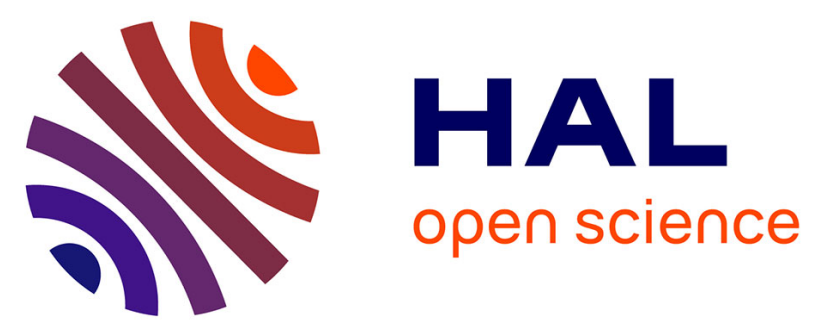

\title{
Agroecosystem diversification with legumes or non-legumes improves differently soil fertility according to soil type
}

Marie Sauvadet, Jean Trap, Gaëlle Damour, Claude Plassard, Karel van den Meersche, Raphaël Achard, Clémentine Allinne, Patrice Autfray, Isabelle Bertrand, Eric Blanchart, et al.

\section{To cite this version:}

Marie Sauvadet, Jean Trap, Gaëlle Damour, Claude Plassard, Karel van den Meersche, et al.. Agroecosystem diversification with legumes or non-legumes improves differently soil fertility according to soil type. Science of the Total Environment, 2021, 795, 10.1016/j.scitotenv.2021.148934 . hal-03390696

\section{HAL Id: hal-03390696 https://hal.science/hal-03390696}

Submitted on 21 Oct 2021

HAL is a multi-disciplinary open access archive for the deposit and dissemination of scientific research documents, whether they are published or not. The documents may come from teaching and research institutions in France or abroad, or from public or private research centers.
L'archive ouverte pluridisciplinaire HAL, est destinée au dépôt et à la diffusion de documents scientifiques de niveau recherche, publiés ou non, émanant des établissements d'enseignement et de recherche français ou étrangers, des laboratoires publics ou privés. 


\section{Journal Pre-proof}

Agroecosystem diversification with legumes or non-legumes improves differently soil fertility according to soil type

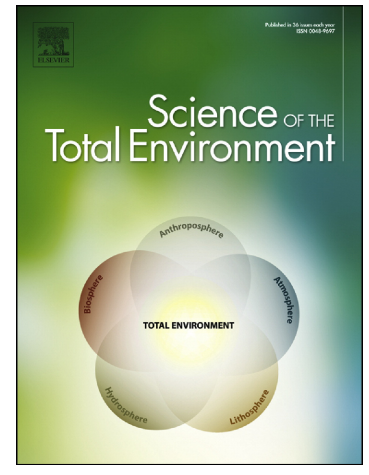

Marie Sauvadet, Jean Trap, Gaëlle Damour, Claude Plassard, Karel Van den Meersche, Raphaël Achard, Clémentine Allinne, Patrice Autfray, Isabelle Bertrand, Eric Blanchart, Péninna Deberdt, Séguy Enock, Jean-Daniel Essobo, Grégoire T. Freschet, Mickaël Hedde, Elias de Melo Virginio Filho, Bodovololona Rabary, Miora Rakotoarivelo, Richard Randriamanantsoa, Béatrice Rhino, Aude Ripoche, Elisabeth Rosalie, Stéphane Saj, Thierry Becquer, Philippe Tixier, Jean-Michel Harmand

PII: S0048-9697(21)04006-7

DOI: $\quad$ https://doi.org/10.1016/j.scitotenv.2021.148934

Reference: $\quad$ STOTEN 148934

To appear in: $\quad$ Science of the Total Environment

Received date: $\quad 26$ March 2021

Revised date: $\quad 3$ June 2021

Accepted date: $\quad 5$ July 2021

Please cite this article as: M. Sauvadet, J. Trap, G. Damour, et al., Agroecosystem diversification with legumes or non-legumes improves differently soil fertility according to soil type, Science of the Total Environment (2018), https://doi.org/10.1016/ j.scitotenv.2021.148934

This is a PDF file of an article that has undergone enhancements after acceptance, such as the addition of a cover page and metadata, and formatting for readability, but it is not yet the definitive version of record. This version will undergo additional copyediting, typesetting and review before it is published in its final form, but we are providing this version to give early visibility of the article. Please note that, during the production process, errors may be discovered which could affect the content, and all legal disclaimers that apply to the journal pertain. 
(C) 2018 C 2021 Published by Elsevier B.V. 
Agroecosystem diversification with legumes or non-legumes improves differently soil fertility according to soil type

Marie Sauvadet ${ }^{1,2,3}$, Jean $\operatorname{Trap}^{1}$, Gaëlle Damour ${ }^{2,3}$, Claude Plassard ${ }^{1}$, Karel Van den Meersche $^{2,4,5}$, Raphaël Achard ${ }^{2,3,6}$, Clémentine Allinne ${ }^{2,5,7}$, Patrice Autfray ${ }^{2,8,9}$, Isabelle Bertrand $^{1}$, Eric Blanchart ${ }^{1}$, Péninna Deberdt ${ }^{2,10}$, Séguy Enock ${ }^{11}$, Jean-Daniel Essobo ${ }^{11}$, Grégoire T. Freschet ${ }^{12,13}$, Mickaël Hedde ${ }^{1}$, Elias de Melo Virginio Filho ${ }^{5}$, Bodovololona Rabary ${ }^{9}$, Miora Rakotoarivelo ${ }^{14}$, Richard Randriamanantsca ${ }^{9}$, Béatrice Rhino ${ }^{2,10}$, Aude Ripoche $^{2,8,9}$, Elisabeth Rosalie ${ }^{2,3,6}$, Stéphane Saj ${ }^{2,7,11}$, Thier y Pecquer $^{1}$, Philippe Tixier $^{2,3}$, Jean-Michel Harmand ${ }^{2,4,11}$

${ }^{1}$ Eco\&Sols, Institut Agro, Univ Montpellier, CIR. ), I VRAE, IRD, F-34060 Montpellier, France

${ }^{2}$ Univ Montpellier, F-34398 Montpellier, r r nce

${ }^{3}$ CIRAD, UPR GECO, F-34398 Montnellier, France

${ }^{4}$ CIRAD, UMR Eco\&Sols, F-34398 Acn'rellier, France.

${ }^{5}$ CATIE (Tropical Agricultural $\mathrm{K}_{\mathrm{u}}$ search and Higher Education Center), Turrialba 7170 ,

Costa Rica.

${ }^{6}$ CIRAD, UPR GECO F 972,35 Le Lamentin, Martinique, France

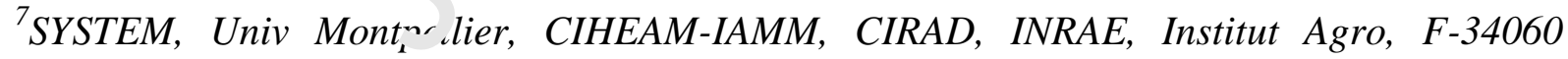
Montpellier, France.

${ }^{8}$ CIRAD, UPR AIDA, BP 110 Antsirabe, Madagascar.

${ }^{9}$ FOFIFA SRR BP 230, Antsirabe, Madagascar.

${ }^{10}$ CIRAD, UPR HORTSYS, F-97285 Le Lamentin, France

${ }^{11}$ ICRAF (World Agroforestry), West and Central Africa Regional Program, Yaounde, Cameroon.

${ }^{12}$ CNRS, Station d'Ecologie Théorique et Expérimentale, F-09200 Moulis, France 
${ }^{13}$ CEFE, Univ Montpellier, CNRS, EPHE, IRD, Univ Paul Valéry Montpellier 3, Institut Agro, INRAE, F-34293 Montpellier, France.

${ }^{14}$ Université d'Antananarivo, Ecole Supérieure des Sciences Agronomiques, BP 175

Antananarivo, Madagascar

Corresponding author: Marie Sauvadet, CIRAD, UPR GECO, F-97285 Le Lamentin, Martinique, France

Email: marie.sauvadet@ cirad.fr

\begin{abstract}
Plant diversification through crop rotation or agrofore try :, a promising way to improve sustainability of agroecosystems. Nonetheless, cri ria to select the most suitable plant communities for agroecosystems diversificatior to ¿ng contrasting environmental constraints need to be refined. Here, we compared th $\ldots$ np. ts of 24 different plant communities on soil fertility across six tropical agroecosystems: t.ther on highly weathered Ferralsols, with strong $\mathrm{P}$ limitation, or on partially weath $\mathrm{re}_{\lrcorner}$c jils derived from volcanic material, with major $\mathrm{N}$

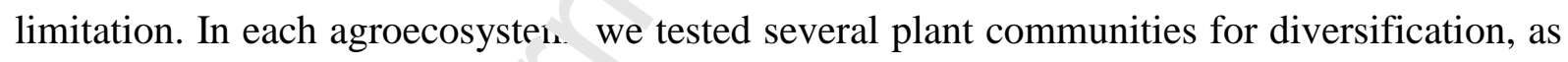

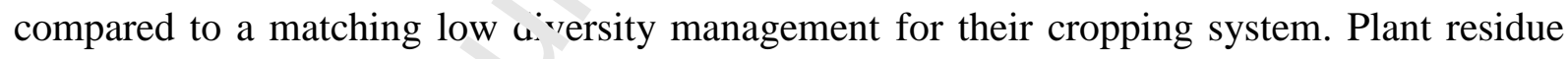
restitution, N, P and lign $\mathrm{n}$ cr ntents were measured for each plant community. In parallel, the soil under each communi y was analyzed for organic $\mathrm{C}$ and $\mathrm{N}$, inorganic $\mathrm{N}$, Olsen $\mathrm{P}$, soil $\mathrm{pH}$ and nematode community composition. Soil potential fertility was assessed with plant bioassays under greenhouse controlled climatic conditions.
\end{abstract}

Overall, plant diversification had a positive effect on soil fertility across all sites, with contrasting effects depending on soil type and legumes presence in the community. Communities with legumes improved soil fertility indicators of volcanic soils, which was demonstrated through significantly higher plant biomass production in the bioassays $(+18 \%)$ and soil inorganic $\mathrm{N}(+26 \%)$ compared to the low diversity management. Contrastingly, 
communities without legumes were the most beneficial in Ferralsols, with increases in plant biomass production in the bioassays $(+39 \%)$, soil Olsen $\mathrm{P}(+46 \%)$, soil $\mathrm{C}(+26 \%)$, and $\mathrm{pH}$ $(+5 \%)$. Piecewise structural equation models with Shipley's test revealed that plant diversification impacts on volcanic soil fertility were related to soil $\mathrm{N}$ availability, driven by litter N. Meanwhile, Ferralsols fertility was related to soil $\mathrm{P}$ availability, driven by litter P. These findings underline the importance of multifactorial and multi-sites experiments to inform trait-based frameworks used in designing optimal plant diversification in agroecological systems.

Key words: C-N-P cycling, functional traits, legumes, ne natodes, plant diversification, tropical soils

\section{Introduction}

Plant diversification is an important evf: to ensure environmentally and nutritionally sustainable food supply in agroe nsystems (Dawson et al., 2019). Agroecosystem diversification can either be achieved or increasing sequential crop diversity (Tiemann et al., 2015) and/or by simultaneous ${ }^{1}$ ch'tivating several species within the field, such as cereal cover crop intercropping or ocra - shade trees intercropping (Tscharnske et al., 2011). Both forms of plant divers, ${ }^{\text {fication }}$ are known to provide a wide range of services such as pest regulation (Ratnadass et al., 2012), the diversification of farm income sources, and a higher food production stability at national levels (Renard \& Tilman, 2019; Díaz et al., 2020). Plant diversification can also improve soil carbon (C) storage and soil fertility, by promoting soil biological activity and facilitating access to nutrients otherwise inaccessible to the main crop (Latati et al., 2016; Duchene et al., 2017). Legume species are especially favored for plant diversification for their ability to fix atmospheric nitrogen $\left(\mathrm{N}_{2}\right)$, hence reducing the need of synthetic $\mathrm{N}$ fertilizers of the agroecosystems (Jensen et al., 2012). However, the services and disservices provided by legume and non-legume plants vary with both the species used and 
the agroecosystems' environmental constraints (Fujii et al., 2018; Waithaisong et al., 2020). A better mechanistic understanding of how plant diversity and its management alter agroecosystem functions will help design efficient cropping systems under a range of environmental conditions.

Greater plant species diversity is assumed to lead to higher ecosystem functionality (Martin and Isaac, 2015; Isbell et al., 2017), since increasing the number of species within an ecosystem increases the probability for plants to display complementary resource requirements and use within the community (Barry et al., 2010). The understanding of plant community relationships with their environment and fite ertects of plant diversity has benefited from trait-based approaches in ecology ratı ${ }^{\circ} \mathrm{r}$ than relying solely taxonomic diversity. Plant functional traits are defined as any $\mathrm{r}_{\mathrm{Ol}_{\mathrm{r}}}{ }^{-h o l o g i c a l,}$ anatomical, physiological, or phenological features measurable at the ir a. id dal level (Violle et al., 2007). They are tightly linked with plant resource acqui 'tic . strategies and plant effects on resource cycling in ecosystems (Freschet \& Roumet, 2717). A trait-based framework using plant traits to design optimal plant community rol rositions for agroecosystems sustainability has been proposed on this principle by Damıur et al. (2018). This approach has been promoted by several reviews and conce 1 papers (Garnier and Navas, 2012; Wood et al., 2015). However, it lacks both (i) piant trait data in agroecosystems (Martin and Isaac, 2015) and (ii) multi-sites studies to consider the influence of contrasting environmental constraints on plant traits - ecosystem functions relationships.

While soil fertility has been linked to plant traits in many studies, how these relationships may be influenced by local ecosystem environmental constraints are less well known (Freschet et al., 2021). For instance, plant $\mathrm{P}$ acquisition can be achieved through the development of its root network and/or through root association with mycorrhizas (Sawers et al., 2017). However, the efficiency of either plant roots network or mycorrhizal symbioses for $\mathrm{P}$ 
acquisition highly depends on overall soil P level, which decreases with soil age (Lambers et al., 2008). Differences in soil $\mathrm{P}$ level also impacts the fixation of atmospheric $\mathrm{N}$ by legume species (Augusto et al., 2013; Batterman et al., 2013); however, while legume species are known to differ in their efficiency to provide N (e.g. Blesh, 2018), how P limitation can affect these differences remains less well known. This question is especially important for tropical agroecosystems, displaying strong contrasts of $\mathrm{N}$ and $\mathrm{P}$ limitations because of the wide range of soil alteration found in these latitudes (Lambers et al., 2008; Hou et al., 2020). Aged, weathered soils such as Ferralsols, which are widely spread in trop:-al countries, are typically more P-limited than younger soils, which are more $\mathrm{N}$-limit $\mathrm{u}$.

Global-scale studies across soil fertility gradients have $t$ idenced the importance of litter $\mathrm{N}$ and $\mathrm{P}$ restitution for soil $\mathrm{N}$ and $\mathrm{P}$ availability in $\mathrm{n}$ t $\mathrm{u}_{\mathrm{n}} \mathrm{l}$ l ecosystems, both for aboveground (Hobbie, 2015; Maire et al., 2015) and below gुı - In $\downarrow$ litter (Bardgett et al., 2014) - although the latter is less studied due to the dif' $: u^{\prime}$ 'y of their measurements. Nutrient release from litter decomposition is driven by the sc: 1 food web, yet both its composition and functioning are heavily altered by anthropic mángement in agroecosystems (de Vries et al., 2013). Nonetheless, several key fooc wet components such as bacterial-feeding nematodes have been observed to promote $1 \mathrm{I}^{+} \mathrm{er}$ and soil organic $\mathrm{N}$ and $\mathrm{P}$ mineralization in agroecosystems (Trap et al., 2016; Ran arısua et al., 2018, 2020). While these food web components can be favored by specific plant communities in natural ecosystems (Wardle et al., 2003; de Deyn et al., 2004), the relationships between plant traits, soil food web and soil fertility have seldom been studied as a whole in agroecosystems. We clearly need to improve our understanding on how plant community traits relate to soil fertility both directly through litter-mediated nutrient cycling feedbacks, and indirectly through food web activity promotion. This could provide new leads to set up a trait-based approach framework for agroecosystem plant diversification (Bender et al., 2016). 
In this context, we studied six tropical agroecosystems - either on highly weathered Ferralsols or on more recent, partially weathered soils derived from volcanic parent material - to compare the influence of plant diversification on soil fertility and soil micro-food web composition. We tested whether (i) plant diversification with legume or non-legume species could improve soil fertility in these contrasting tropical agroecosystems and soil types, (ii) diversification impacts on soil fertility could be linked to plant communities' traits, and (iii) soil fertility - plant communities relationships understanding could be improved with the characterization of changes in soil micro-food web composition

\section{Materials and Methods}

\section{1. $\quad$ Sites and sampling strategy}

Six experimental sites, within the CIRAD - IRn , letwork and collaborating institutions in tropical countries (Cameroon, Costa Rica. $\mathbf{M}$ : dagascar and Martinique, West Indies) (Table 1) were selected. Two main types of, lant diversification were considered: rotational diversification (at 3 sites; tomato, rir: anı banana based-cropping systems) and agroforestry (at 3 sites; shade trees intercrops ny in cocoa, organic coffee and conventional coffee basedcropping systems). For each twial crop (tomato, rice, banana, cocoa, organic coffee and conventional coffee), thr e i n l1ve combinations of crop / additional species (hereafter called "plant communities") $w_{1} \geqslant$ replicated in three to eight blocks, accounting for a total of $n=142$ observations (Table 1).

The trials were carried out on soils with two contrasting levels of soil mineral fertility: highly weathered Ferralsols with high P-limitation for Rice and Cocoa agroecosystems, and partially weathered soils derived from volcanic parent material for Tomato, Banana, Organic and Conventional Coffee sites (Nitisols, Cambisols and Acrisols), with expected major limitation in $\mathrm{N}$ (Lambers et al., 2008). Crop rotational diversification (i.e. diversification over time) corresponded to a plant community growing in rotation with the focal crop. At the end of the 
first growing season, the plant communities were cut and left in the field as a mulch on soil surface until crop sowing. One notable exception was the residues of Allium fistulosum from the Tomato site, whose integral aboveground biomass was harvested and hence exported from the field in both A. fistulosum / Tomato and A. fistulosum + Crotalaria spectabilis / Tomato rotations (Table 1). Although banana is a multiannual crop, only the sowing and cutting of different plant communities and the subsequent first year of banana cropping was considered, to be comparable with the other sites testing rotational diversification (i.e. Tomato and Rice). On the other hand, the agroforestry trials (i.e. simultaneous ass ciation in the same area) compared coffee or cocoa intercropped with different shad $\mathbf{u}^{\circ}$ e species with unshaded coffee or cocoa systems, respectively (Table 1).

Each of the six sites was hence designed to ass sss the impact of plant diversification compared to a reference treatment. The referer $a$ tre atment in each site was the treatment that represented the lowest diversity manag me.tt: crop without shade tree in agroforestry sites, rice / rice two-stages rotation in Rice s: ${ }^{\text {te, }}$ and 170-days spontaneous grassing (i.e. no active sowing) / tomato and 245-days snon. ar.eous grassing / banana in Tomato and Banana sites (Table 1).

\subsection{Plant samplin。 $\mathrm{a}$ id community traits measurements}

Assessment of annual ab veground biomass restitution depended on diversification type. In rotational systems, plant communities' aboveground biomass was cut, and restituted as a mulch on soil surface during the first growing season. Residue restitution was assessed by harvesting and weighing one subplot of $1 \mathrm{~m}^{2}$ in each block. Plant communities consisted of one to several species per treatment (Table 1) that were studied jointly (i.e. not separated by species during the sampling and analysis processes). In coffee and cocoa agroforestry systems, aboveground biomass restitution was assessed with litter collectors placed under the canopies of shade trees and crop; leaf litterfall from both the focal crop (cocoa or coffee) and 
the intercropped shade trees was collected and weighed at several times throughout the main litterfall season (see Sauvadet et al. (2020) for further details).

A composite sample of the litter collected from each community was then used to analyze plant community litter traits (Table $\mathrm{S} 1$ ). Total $\mathrm{C}$ and $\mathrm{N}$ contents were determined by dry combustion using a CHN micro-analyzer (Carlo Erba NA 2000, Milan, Italy). For total P content, $50 \mathrm{mg}$ of ground litter were mixed with $65 \% \mathrm{HNO}_{3}$, then mineralized at $200^{\circ} \mathrm{C}$ during 15 min in a Milestones ETHOS ESAY microwave, together with standard and blank. Phosphorus content was quantified colorimetrically using the yellow vanadomolybdate reagent (Neves et al., 2008) with modification. Bri -11; ammonium heptamolybdate tetrahydrate $\left(20 \mathrm{~g} \mathrm{~L}^{-1}\right)$ was first dissolved in $200 \mathrm{~mL}$ of cirionized water with ammonia (2 ml $\left.\mathrm{L}^{-1}\right)$. Ammonium vanadate $\left(0.47 \mathrm{~g} \mathrm{~L}^{-1}\right)$ was added int $100 \mathrm{~mL}$ of hot deionized water and slowly acidified with $1 \mathrm{ml}$ of $65 \% \mathrm{HNO}_{3}$. Afte: a di ion of $100 \mathrm{~mL}$ of water and cooling, both solutions were mixed together with $90 \mathrm{r}_{\mathrm{r}}{ }^{\prime} \mathrm{o}^{f} 65 \% \mathrm{HNO}_{3}$ and completed to $1 \mathrm{~L}$ with deionized water. The colored reaction was carrit.' out by mixing the extract with deionized water and vanadomolybdate reagent. Overal ${ }^{1}$ th rensitivity of the assay was $0.36 \mathrm{mg} \mathrm{P} \mathrm{g}^{-1} \mathrm{DM}$. Lignin content was obtained by the $\cdots n$ Suest method (Van Soest, 1963) with a Fibersac 24 fiber analyser (Ankom, Macedon, NI, USA). Litter quality of $C$. arabica in both Costa Rican sites (Organic Coffee and L'nventional Coffee) and of E. poepiggiana and T. amazonia in the Conventional Coffee site could not be analyzed. We therefore estimated them from the review of Petit-Aldana et al. (2019) and from results in the Organic Coffee site, respectively.

\section{3. $\quad$ Soil sampling, nematodes and soil fertility indices measurements}

All soil analyses were performed on one composite soil sample per block of about $2 \mathrm{~kg}$ fresh soil from the $0-10 \mathrm{~cm}$ soil layer, corresponding to the zone of influence of aboveground litter deposition, at the key stage of crop development (i.e. flowering for rice and tomato and fruiting for banana, coffee and cocoa). The composite soil sample was obtained from 7 to 10 
random locations within the main crop inter-rows in rotational systems, and around coffee and cocoa plants; in the case of agroforestry systems, the sampling was performed around coffee and cocoa plants that were under the canopy of the associated shade trees. Composite soils were carefully homogenized before being sub-sampled for nematode extraction and identification (used as a proxy of soil food web), and soil fertility components: plant bioassay production and soil chemical fertility (Table S1).

Nematode communities were characterized both to assess the impacts of agricultural practices on soil health (Ritz and Trudgill, 1999) and for their key roles in $\complement \mathrm{N}$ and P cycling through the microbial loop theory (Bonkowski, 2004). Nematode, w are extracted from $250 \mathrm{~g}$ fresh soil samples by elutriation (Seinhorst, 1950) and were rou.ted with a stereomicroscope $(\times 40)$. Nematodes were fixed in a 4\% formaldehyde solutic . . hen, 200 specimens per sample were randomly selected on glass slides and idertı." ed to the genus level with a compound microscope $(\times 400)$ (Nematrops Lab, rat sry, Dakar, Senegal). Nematode community composition was used to calculate gent $\cdot\urcorner$ richness and Shannon diversity index at the level of the genus. Each nematode genus was tr.en assigned to a trophic group (Yeates et al., 1993),

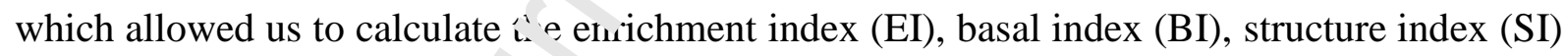
and the Nematode Chann' atio (NCR). EI, BI and SI indicate the proportion of opportunistic, basal anc 'Dculalists' taxa within the micro-food web, respectively (Ferris et al., 2001; Berkelmans et al., 2003). NCR indicates the proportion of bacterial-feeding nematodes - considered important for nutrient cycling promotion - within microbial-feeder nematodes (Yeates, 2003).

Fresh, coarsely homogenized soil was used for the measurement of soil inorganic $\mathrm{N}$ content with a 1:4 soil $1 \mathrm{M} \mathrm{KCl}$ solution mixture. $\mathrm{NO}_{3}{ }^{-}$and $\mathrm{NH}_{4}{ }^{+}$were determined by continuous flow colorimetry (TRAACS 2000, Bran and Luebbe, Norderstedt, Germany). Another aliquot of fresh, coarsely homogenized soil was used for a greenhouse plant bioassay, an off-site 
assessment of "soil biochemical fertility" of the ecosystem, which relies on the short-term growth of seedlings of a model plant in soils collected beneath plant communities (Dybzinski et al., 2008). Briefly, 2-L pots were filled with $1.40 \pm 0.01 \mathrm{~kg}$ of fresh soil from composite soil samples per block. Four seeds of maize (Zea mays L.) cv. CIRAD 412 were then sown into each pot; only two seedlings were left in each pot after sprouting of the seeds. The maize seedlings were grown in a greenhouse with manual watering to maintain soil at its optimal water holding capacity. After 45 days of vegetative growth, shoots and roots of the plants were harvested, washed, dried at $65^{\circ} \mathrm{C}$ for 2 days, and wejohec to obtain the above- and belowground dry biomasses. We refer to the biomass rumined by this method as "plant bioassay" in the rest of the article and in the illustrations.

A final soil subsample of $260 \mathrm{~g}$ was thoroughly mixt: then sieved at $2 \mathrm{~mm}$ and air-dried before analysis of total $\mathrm{C}$, total $\mathrm{N}$, Olsen $\mathrm{P}$ ard ${ }_{2} \mathrm{H}\left(\mathrm{H}_{2} \mathrm{O}\right)$. Total soil organic $\mathrm{C}$ and $\mathrm{N}$ were determined by dry combustion of dry oj' subsamples ground to $0.2 \mathrm{~mm}$, using a $\mathrm{CHN}$ microanalyzer (Carlo Erba NA 2000, N:ilan, Italy). Soil pH $\left(\mathrm{H}_{2} \mathrm{O}\right)$ was determined by mixing $2 \mathrm{~g}$ of dry soil with $10 \mathrm{~mL}$ of deionize $\mathrm{d}$ water for $30 \mathrm{~min}$. Olsen $\mathrm{P}$ content was measured from Olsen (1954). Briefly, $250 \mathrm{mg}$ of dı y soil were extracted with $5 \mathrm{~mL}$ of $0.5 \mathrm{M} \mathrm{NaHCO}_{3}$ at $\mathrm{pH}$ 8.5 by 30 min shaking. $\mathrm{P}$ in the extract was then measured according to the malachite green method (Rao et al., 19y??

\subsection{Statistical analyses}

Inherent site differences in soil fertility and nematode community composition were first assessed through a comparison between each site reference treatment (Table 1) with generalized linear models coupled with post hoc HSD Tukey tests (Table 2).

In a second step, site reference treatments were used to assess the impact of plant diversification on soil fertility according to Hedges et al. (1999). First, log response ratio $\left(\mathrm{LRR}_{\mathrm{i}}\right)$ was calculated for each site and soil variable: 


$$
L R R i=\ln \left(\frac{\text { Treatment } \mathrm{i}}{\text { Reference Treatment }}\right)
$$

where "Treatment $i$ " is the treatment value at the plot $\mathrm{i}$, and "Reference Treatment" the reference treatment mean value for the corresponding site. The log response ratio of nematode indices was calculated similarly after the addition of the value 1 to both the numerator and denominator to avoid errors caused by null values. This metric reflects a change of the variable relative to the site reference treatment; positive and negative values of $\mathrm{LRR}_{i}$ represent respectively a positive and negative effect of plant diversification relatively to its reference treatment. For each variable, we then assessed the me $n \log$ response ratio $L_{R} R_{m}$ according to two crossed factors: presence of legume 1. the community (with legume without legume), and soil type (volcanic soils - Fer alsols), resulting in four different categories. $\mathrm{LRR}_{\mathrm{m}}$ was calculated according to $e_{\text {qu }}$ tion 2 and estimated the $95 \%$ confidence interval around $\mathrm{LRR}_{\mathrm{m}}$ using bootstrappins ${ }_{1}^{\prime}(\mathrm{N}$ iterations) for each category with the $\{$ boot $\}$ R package.

$$
L R R=\frac{\sum L_{R R}}{n}
$$

where $\mathrm{n}$ corresponds to the thal number of observations of each category. $\mathrm{LRR}_{\mathrm{m}}$ was calculated for all soil fertilı: 'nd nematodes indices and was considered significant if its $95 \%$ confidence interv. ${ }^{1}$ ciu not overlap with zero.

The plant community traits were first used in a principal component analysis (PCA) to identify trait covariation patterns and the main differences between plant communities across all sites. We then used generalized linear models coupled with the post hoc HSD Tukey test to assess the significance of legume presence and soil type on plant community traits. A first global analysis of relationships between plant community traits, soil fertility and nematode indices was performed with a Pearson correlation coefficient matrix, corrected for multiple comparison with the Benjamini-Hochberg method. This analysis allowed selecting the most 
pertinent variables to include in a following analysis of piecewise Structural Equation Models (pSEMs). The psem function of the \{piecewiseSEM\} R package (Lefcheck, 2015) was used in order to include the site identity as a random effect for each linear mixed-effects equation. Linear mixed effects equations were built as a first step according to the observed bivariate and multivariate relationships. Shipley's test of d-separation (Shipley, 2009) was then used to assess the overall fit of the pSEMs and whether paths were missing from the model. All statistical analyses were performed using R software (R-3.6.2) and the following packages: ade4, boot, emmeans, factoextra, FactoMineR, ggplo ${ }^{\text {? }}$ :me4, multcomp, nlme, piecewiseSEM, psych, readxls, reshape2 and stats.

\section{Results}

\subsection{Plant community traits}

Plant community traits greatly differed betwe, the communities according to (i) the presence of legumes in the community and (ii) the . pe of soil where the community was grown (Fig 1). Legume presence in plant comm ...itı? significantly increased litter $\mathrm{N}$ content $(2.3 \pm 1.2$ against $1.3 \pm 0.4 \% \mathrm{DM}$ without egı mes, P-value < 0.01 ) across all sites, but did not impact significantly litter P content $<$ h a amount of aboveground biomass returned to the soil (Fig S1). On the other hand, pla nt communities from Ferralsols (i.e. Rice and Cocoa sites) had lower litter $\mathrm{P}$ contents th. $\mathrm{n}$ sites on volcanic soils $(0.08 \pm 0.03$ against $0.21 \pm 0.07 \% \mathrm{DM}$, respectively, $\mathrm{P}$-value $<0.001)$, and higher lignin content $(39.2 \pm 7.9$ against $26.6 \pm 8.4 \% \mathrm{DM}$, respectively, P-value $<0.001$, Fig S1). The amount of biomass restitution did not differ between volcanic soils and Ferralsols and was higher in Banana and Tomato sites than in the other sites (Fig 1).

\subsection{Differences in soil fertility and nematode indices across sites reference}


Soil $\mathrm{pH}$ was acid to slightly acid across all sites and ranged between $5.0 \pm 0.1$ for the Conventional Coffee site to $6.6 \pm 0.1$ for the Cocoa site (Table 2). Sites on Ferralsols (Rice and Cocoa) had the lowest total $\mathrm{C}\left(18.0 \pm 0.9\right.$ and $15.4 \pm 5.3 \mathrm{~g} \mathrm{C} \mathrm{kg}^{-1}$ soil, respectively) and $\mathrm{N}$ contents, the highest soil $\mathrm{C}$ to $\mathrm{N}$ ratio, and the lowest Olsen $\mathrm{P}$ content (inferior to $8.0 \mathrm{mg} \mathrm{P} \mathrm{kg}{ }^{-}$ ${ }^{1}$ soil). On the other hand, Conventional and Organic Coffee sites presented the highest soil C, $\mathrm{N}$ and Olsen $\mathrm{P}$ contents, and produced 2.1 to 4.7 times more biomass in the plant bioassay than the other sites (Table 2). Tomato and Banana sites presented intermediate values for most soil fertility indices, except for inorganic $\mathrm{N}$ content and plant hinas ay, which were one of the lowest for Tomato site.

Total free-living and bacterial-feeding nematodes de'sli's were the highest (more than 2900 and 1600 ind $\mathrm{kg}^{-1}$ soil, respectively) in Organic Coffee, Cucoa, Rice and Tomato sites, and the lowest in Conventional Coffee and Banana sites (less than 1000 and 300 ind $\mathrm{kg}^{-1}$ soil, respectively) (Table 2). Densities of funy 1 -feeders were the greatest in Rice, Tomato and Organic Coffee sites, while Omnivors, Carnivores and Plant-feeding nematodes were more abundant in Banana, Cocoa and I.⿲丿丨 sites (Table 2). Nematode genera richness and Shannon Index were the highest in Prg.nic Coffee, Cocoa and Tomato sites, and the lowest in Conventional Coffee sit .. i'ernatode communities under the agroforestry systems (Cocoa, Organic and Convention ' ${ }^{\prime}$ Coffee) presented higher Nematode Channel Ratio (NCR), while communities under Tomato and Banana sites presented higher Enrichment Index (EI). Nematode communities in Organic and Conventional Coffee sites presented higher Basal Index (BI), but lower Structure Index (SI).

\subsection{Effects of plant diversification on soil fertility and nematodes indices}

Plant diversification impacts on soil fertility and nematode communities depended on both plant communities and soil type (Fig 2). First, legume inclusion in the system globally increased soil inorganic $\mathrm{N}$ content in both volcanic soils and Ferralsols, albeit only 
significantly for the former (Fig 2a). However, the other fertility indices responded differently depending on both legume presence in plant communities and soil type. Indeed, on volcanic soils, diversification with legumes significantly increased plant bioassay, soil $\mathrm{N}$ content, soil $\mathrm{pH}$, decreased soil C:N ratio and showed no impact on soil Olsen $\mathrm{P}$, while the non-legume communities had no or negative impacts on volcanic soil fertility (e.g. significant decrease of plant bioassay).

Contrastingly, plant diversification on Ferralsols significantly increased soil Olsen P content, regardless of the presence of legumes within the commur t1e Non-legume communities were the most beneficial to Ferralsols, with a significant acre ıse of plant bioassay, soil total $\mathrm{C}$ and $\mathrm{N}$ contents, and soil $\mathrm{pH}$. In contrast, divess.cation with legumes in Ferralsols decreased soil $\mathrm{pH}$, increased soil $\mathrm{C}: \mathrm{N}$ ratio and had no significant impacts on plant bioassay and soil $\mathrm{C}$ and $\mathrm{N}$ contents (Fig 2a).

The introduction of legumes decreased the $\iota$ tal abundance of omnivorous and plant-feeding nematode populations in both soil $t \mathrm{p}_{i}$ albeit only significantly in Ferralsols (Fig $2 \mathrm{~b}$ ). The introduction of legumes also inc1 asea the nematodes Basal Index in Ferralsols and decreased the total free-living nemato ' ${ }^{\prime}$ taxonomic richness in volcanic soils. Finally, plant diversification decreasec the nematodes Basal Index in volcanic soils, regardless of legume presence in the commurit $y$.

3.4. Relationships between plant community traits, soil fertility, and nematode indices

Litter $\mathrm{N}$ and $\mathrm{P}$ contents were positively correlated to soil inorganic $\mathrm{N}$ and Olsen $\mathrm{P}$ contents, respectively ( $\mathrm{r}$ of 0.55 and 0.29 , respectively, Fig 3). Litter $\mathrm{N}$ and $\mathrm{P}$ contents were also positively correlated with soil $\mathrm{C}$ and $\mathrm{N}$ contents ( $\mathrm{p}$-value $<0.05$ in all cases). However, soil $\mathrm{C}$ content presented better correlations with soil inorganic N and Olsen P ( $\mathrm{r}$ of 0.68 and 0.68 , 
respectively, p-values $<0.001)$ than with any plant community traits (Fig 3). Similarly, plant bioassay was better correlated with soil variables than with plant community traits, especially with soil $\mathrm{C}(\mathrm{r}=0.81, \mathrm{p}$-value $<0.001)$, soil inorganic $\mathrm{N}(\mathrm{r}=0.77$, $\mathrm{p}$-value $<0.001)$ and soil Olsen P $(r=0.65$, p-value $<0.001)$ contents (Fig 3 and S2). Nematode indices presented only weak correlations with plant community traits; nematode bacterial-feeders abundance and Basal Index showed significant yet weak correlations with soil inorganic $\mathrm{N}$ and soil $\mathrm{C}$ content, respectively ( $\mathrm{r}=0.26$ and 0.30 , respectively, p-values < 0.05) (Fig 3). However, soil $\mathrm{pH}$ was the best variable correlated to several nematode indices, such main trophic groups abundance, diversity and food web indexes (Fig 3 and S3).

Based on these observations, piecewise structural eq $t$ at $\urcorner$ models were built and included a random site effect for each equation (Fig 4). Annlication of the model to the whole dataset showed that plant bioassay increased signifi antıy with both soil $\mathrm{N}$ and $\mathrm{P}$ availability (Pvalues < 0.001) (Fig. 4a). Soil $\mathrm{N}$ availabilı.' increased with plant community litter $\mathrm{N}$ and soil $\mathrm{C}$ content, while soil $\mathrm{P}$ availability i - rec $\mathrm{r}$ sed with soil $\mathrm{C}$ content and to a lesser extent with nematodes Basal Index. Separate a nalyses per soil type showed contrasting relationships between plant community taits, soil fertility and nematode indices (Fig $4 \mathrm{~b}$ and $4 \mathrm{c}$ ). In Ferralsols (Rice and Co - Va sies), soil P availability increased with both plant community litter P and soil C conten (Fig 4b), and was significantly correlated with plant bioassay. In these sites, soil $\mathrm{N}$ availability increased significantly with litter $\mathrm{N}$ content but had no significant relationship with plant bioassay. In volcanic soils (Tomato, Banana and Coffee sites), both plant community litter $\mathrm{N}$ and soil $\mathrm{C}$ contents explained soil $\mathrm{N}$ availability, while nematode Basal Index increased significantly with soil P availability. In these soils, the soil $\mathrm{N}$ availability - plant bioassay correlation was four times stronger than the soil P availability plant bioassay correlation ( $\mathrm{r}$ of 0.52 and 0.13 , respectively), despite being both significant (Pvalues inferior to 0.001 and 0.05 , respectively). 


\section{Discussion}

\subsection{Plant community traits - soil fertility - micro-food web relationships vary with soil type.}

In line with our expectations, plant diversification had overall positive effects on soil fertility across all sites, yet these effects varied greatly with the pedological conditions. First, each site tested a set of plant communities susceptible to improve agroecosystem services in its local context. Therefore, not only soil fertility, but also plant ccmmunity traits varied greatly among the six sites. This was especially apparent for sites on Ferralsols (Rice and Cocoa sites) which presented lower soil P availability (Walkes : an 1 Syers, 1976), but also plant communities with lower litter P content, as a conseq ten e of P limitation for growth (Han et al., 2011; Raminoarison et al., 2020). Differenres in nutrient limitations for plant growth between Ferralsols and volcanic soils were a: $\mathrm{n}$ evidenced by the greenhouse plant bioassay, an off-site assessment of soil potential fer : ity (Dybzinski et al., 2008, Sauvadet et al., 2019, 2020). Plant bioassay presented strr -9 - orrelations with the most limiting element for its growth (Fig S2) - i.e., $\mathrm{P}$ in Ferra so: and $\mathrm{N}$ more than $\mathrm{P}$ in volcanic soils. These results are in line with the common fincing in literature, describing a shift between $\mathrm{N}$ and $\mathrm{P}$ limitation with soil weathering sta ge 'Lambers et al., 2008; Hou et al., 2020), and were consistent between the sites despite ineir differences in management and fertilization.

Soil C content also presented strong positive correlation with plant bioassay, supporting the concept of soil fertility promotion by soil organic matter (Manlay et al., 2007), which was further supported by the positive correlations found with soil $\mathrm{N}$ and $\mathrm{P}$ availability. Indeed, due to constrained stoichiometric ratios of soil organic matter, soil $\mathrm{C}$ enrichment implies soil total $\mathrm{N}$ and $\mathrm{P}$ increase (e.g. Kirkby et al., 2011), along with improved biological activity, leading to faster $\mathrm{N}$ and $\mathrm{P}$ turnover (Craswell and Lefroy, 2001). Interestingly, correlations strength between soil $\mathrm{C}$ and nutrient availability depended on the most limiting nutrient for plant 
growth; soil $\mathrm{C}-\mathrm{P}$ availability link was significant only in Ferralsols, while soil $\mathrm{C}-\mathrm{N}$ availability relationship was significant only in volcanic soils (P-values $<0.01$ and 0.001 , respectively, Fig 4). While soil $\mathrm{C}$ relationships with $\mathrm{N}$ and $\mathrm{P}$ availability are not so easily found because of differences in turnover time or P sorption mechanisms on soil constituents (Kruse et al., 2015; Plassard et al., 2015), our experimental design allowed to focus on plant communities - based relationships for both soil types. Consequently, relationships between soil $\mathrm{C}$ and soil $\mathrm{N}$ and $\mathrm{P}$ availability mirrored these between soil $\mathrm{C}$ and plant community litter $\mathrm{N}$ and $\mathrm{P}$ content in this study, suggesting that the plant comminil-s producing litter of high nutrient contents could have provided the additional $\mathrm{N}$ an ${ }^{i} \mathrm{r}$ required to store more $\mathrm{C}$ in soil superficial layer, while keeping soil organic matter stoirh $h_{\mathfrak{1}}$ metric ratio (Bertrand et al., 2019). These relationships are likely to occur due to cumulstiv effect over several years. In support for our second objective we demonstrate here $t_{1}$. it '.ey plant community traits can be linked with soil fertility increase across contras ng agroecosystems.

Soil $\mathrm{N}$ availability was indeed linker vili. litter $\mathrm{N}$ content, and to a lesser extent to bacterialfeeder nematode abundance. Wh te he impacts of plant litter $\mathrm{N}$ on soil $\mathrm{N}$ dynamics has long been acknowledged (Manzor: eı ^1., 2008, Hobbie, 2015), the promoting effects of bacterialfeeder nematodes on sc: i $^{\top}$ availability through bacterial grazing (Bonkowski, 2004) has more recently been consı tered at different scales (de Vries et al., 2013; Trap et al., 2016). Given the sensitivity of this trophic group to soil pH (van den Hoogen et al., 2019), avoiding practices with strong soil acidification impacts such as massive ammonium-based fertilization is of upmost importance (Stumpe and Vlek, 1991; Goulding, 2016). Similarly, soil P availability was both correlated with litter $\mathrm{P}$ and nematode community structure, albeit with a lesser strength than for $\mathrm{N}$ availability. Indeed, while the role of litter P content (Damon et al., 2014; Maire et al., 2015) and nematode top-down regulation (Ranoarisoa et al., 2018, 2020) has been recognized to improve soil $\mathrm{P}$ availability, the diversity of $\mathrm{P}$ forms and their complex 
interactions with soil matrix hampers the generalization of these relationships across agroecosystems (Kruse et al., 2015; Plassard et al., 2015). Plant diversification has hence been shown to impact contrastingly $\mathrm{P}$ cycling through the promotion of different $\mathrm{P}$ forms and $\mathrm{P}$ solubilization processes, depending on both plant communities and soil type (Waithaisong et al., 2020). Differences in P cycling processes between soil types could explain the absence of nematode community - Olsen P correlations in Ferralsols (Fig 4), however this assumption would have needed the characterization of more $\mathrm{P}$ forms to be fully answered. These differences of $\mathrm{P}$ assimilation strategy could also have been tu ther comforted with the characterization of root traits and mycorrhizal symbic ses indicative of plant $\mathrm{P}$ uptake capacity, as well as the activity of P-mineralizing $a_{1}{ }^{-1}$-solubilizing microorganisms in addition to their nematodes grazers (indicating soil $? \mathrm{p}$ tential availability) (e.g. Becquer et al., 2014).

\subsection{Implications for plant comm 'nity selection for agroecosystems diversification}

Plant community traits - soil fertilit $/$ _ nicro-food web composition relationships give useful insights to understand the $i_{1} \cdot$ nacıs of managed plant community composition on agroecosystems functioning. $G_{1}$ the one hand, volcanic soils, presenting higher limitation for $\mathrm{N}$, benefitted more from pla it communities including legumes, which produced $\mathrm{N}$-enriched litter due to their $\mathrm{N}_{2}$-firirg ability and improved soil total $\mathrm{N}$ and inorganic $\mathrm{N}$ contents along with plant bioassay (see Sauvadet et al., 2019, for more details). These results are in line with global findings in temperate, N-limited agroecosystems (Drinkwater et al., 1998). Further, the introduction of legume species led to similar increase of plant community litter-N and soil $\mathrm{N}$ availability in both Ferralsols and volcanic soils, suggesting that the legume species grown on the Ferralsols sites may be well adapted to fix atmospheric $\mathrm{N}_{2}$ in limited P-availability conditions (Augusto et al., 2013), likely thanks to their high capacity to mobilize soil P (Hinsinger et al., 2003). However, increases in $\mathrm{N}$ availability under legume communities did 
not improve plant bioassay in Ferralsols as they did in volcanic soils. This lack of effects may be caused by Ferralsols P- rather than N-limitation for plant growth, which was not improved by the presence of legume (Fig 2). Even more, the increased $\mathrm{N}$ provision by legumes in Ferralsols, combined with low $\mathrm{N}$ uptake, may have led to nitrification and subsequent nitrate leaching, leading to proton production (van Breemen, 1983; De Vries et al., 1987), and causing the observed Ferralsols acidification under legume communities (Fujii et al., 2018).

Ferralsols acidification by legumes may have hampered bislogical activity, which could explain the absence of other benefits of plant community dive isil; on soil fertility as observed with non-legume communities, despite similar levels if $\mathrm{n}$ itrient availability. First, soil acidification by legumes may have decreased in part $\mathbf{r}$. váilability (Plassard et al., 2015), in particular in the Rice site which had a low initial pH. This process may not have been detected in this study because of the use of th. OIsen $\mathrm{P}$ protocol ( $\mathrm{pH} 8.5$ extractant) to assess P availability (Kruse et al., 2015), as the a ence of significant soil pH - Olsen P relationships in Fig 3 may suggest. Second, soil ar:-ditı ation under legumes likely disturbed soil biological activity and led in some cases to ,oli $₹$ loss despite good nutrient availability (see Sauvadet et al. (2020) for more detail ). Tverall, these results question the use of legumes for agroecosystem diversific au $\eta$ when soil $\mathrm{P}$ availability is too low, and highlight the strong dependency of plant com runity traits - soil fertility relationships with the local pedoclimatic context. This dependency underlines the importance of assessing the limiting factors of agroecosystems' soil fertility, and their interactions with other soil properties, in order to determine which plant community traits to favor when diversifying agroecosystems.

\section{Conclusion}

Our study highlighted the importance to consider both pedoclimatic constraints and plant community traits to build diversified agroecological cropping systems. The presence of legumes - widely favored for their well-known benefits in N-limited agroecosystems - does 
not appear determinant for soil fertility in more weathered soils presenting strong P limitation such as Ferralsols. Soil fertility in such soils was driven by plant community traits directly linked with $\mathrm{P}$ cycling. This was evidenced by a shift of the key traits promoting soil fertility between volcanic soils and Ferralsols in pSEMs analysis. While the traits used in this work were generic because of the heterogeneity of the agroecosystems studied (annual and agroforestry systems), these first results highlight the need to further test a range of more specific traits linked to $\mathrm{N}$ and $\mathrm{P}$ acquisition and build-up in soil, such as root traits and more specifically mycorrhizal symbiosis, (Freschet et al., 2021). Furthe. more, practices improving both soil $\mathrm{pH}$ and soil $\mathrm{C}$ should be promoted for their stror $\mathrm{g}$ in $\mathrm{k}$ Ks with nematode indices (and likely microbial community structure), and $\mathrm{N}$ and $\mathrm{P}$ arailability for plants, respectively. Overall, our findings evidenced important challengəs : hat will have to be solved before a framework can be laid out for designing tra $t-a s^{\prime} d$ plant communities suited for tropical agroecosystems for a wide range of pedc lir ates.

\section{Acknowledgements}

The present work was funded $i_{。}$ ' the Agropolis Foundation, STRADIV project (no. 1504003), CIRAD (Centre de Cou `ération Internationale en Recherche Agronomique pour le Développement), IRD (l ıstit it de Recherche pour le Développement). Part of this work was also carried out within the framework of the CGIAR Research Program on Forests, Trees and Agroforestry (FTA). We are grateful to the different people who helped with plant and soil sampling and analyses: Fanny Baronnet, Yamei Chen, Romain Domingo, Shu Festus, Laura Floch, Baba Gaspard, Jean Larvy-Delarivière, Patricia Leandro, Victor Hugo Mendez Sanabria, Rose N'dango, Nancy Rakotondrazafy, Jean-Marc Souquet, Najat Talha, and Joëlle Toucet. We are grateful to Michel Roux-Cuvelier from CIRAD - La Réunion for providing us the seeds for the maize bioassay.

\section{Data availability}


Data associated with this paper will be available on Dryad.

\section{References}

Augusto, L., Delerue, F., Gallet-Budynek, A., Achat, D.L., 2013. Global assessment of limitation to symbiotic nitrogen fixation by phosphorus availability in terrestrial ecosystems using a meta-analysis approach. Global Biogeochemical Cycles 27, 804-815. https://doi.org/10.1002/gbc.20069

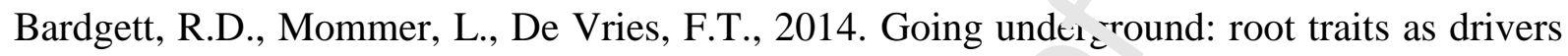
of ecosystem processes. Trends in Ecology \& Evolution 29, 692-699. https://doi.org/10.1016/j.tree.2014.10.006

Barry, K.E., Mommer, L., Ruijven, J. van, Wirth, C., 'Vright, A.J., Bai, Y., Connolly, J., Deyn, G.B.D., Kroon, H. de, Isbell, F., Miiı", A., Roscher, C., Scherer-Lorenzen, M., Schmid, B., Weigelt, A., 2019. The ${ }^{\mathrm{r}}$.ure of Complementarity: Disentangling Causes from Consequences. Trends in Ecology \& Evolution 34, 167-180. https://doi.org/10.1016/j.tree.2r19.. ^.013

Batterman, S.A., Wurzburge, N., Hedin, L.O., 2013. Nitrogen and phosphorus interact to control tropical symk otı N2 fixation: a test in Inga punctata. Journal of Ecology 101, 1400-1408. https://do1. org/10.1111/1365-2745.12138

Becquer, A., Trap, J., Irshad, U., Ali, M.A., Claude, P., 2014. From soil to plant, the journey of $\mathrm{P}$ through trophic relationships and ectomycorrhizal association. Front. Plant Sci. 5. https://doi.org/10.3389/fpls.2014.00548

Bender, S.F., Wagg, C., van der Heijden, M.G.A., 2016. An Underground Revolution: Biodiversity and Soil Ecological Engineering for Agricultural Sustainability. Trends Ecol. Evol. (Amst.) 31, 440-452. https://doi.org/10.1016/j.tree.2016.02.016 
Berkelmans, R., Ferris, H., Tenuta, M., van Bruggen, A.H.C., 2003. Effects of long-term crop management on nematode trophic levels other than plant feeders disappear after 1 year of disruptive soil management. Applied Soil Ecology 23, 223-235. https://doi.org/10.1016/S0929-1393(03)00047-7

Bertrand, I., Viaud, V., Daufresne, T., Pellerin, S., Recous, S., 2019. Stoichiometry constraints challenge the potential of agroecological practices for the soil $\mathrm{C}$ storage. A review. Agron. Sustain. Dev. 39, 54. https://doi.org/10.1007/s13593-019-0599-6

Blesh, J., 2018. Functional traits in cover crop mixtures: l'iols gical nitrogen fixation and multifunctionality. Journal of Applied Ecology 55, 3১ $4^{\varsigma}$. https://doi.org/10.1111/13652664.13011

Bonkowski, M., 2004. Protozoa and plant grov tr.: he microbial loop in soil revisited. New Phytologist 162, 617-631. https://doi',rg/ 0.1i11/j.1469-8137.2004.01066.x

Craswell, E.T., Lefroy, R.D.B., 2001. 1. a role and function of organic matter in tropical soils, in: Martius, C., Tiessen, H., r'ok, Y.L.G. (Eds.), Managing Organic Matter in Tropical Soils: Scope and Limitation $:$ Proceedings of a Workshop Organized by the Center for Development Research al the University of Bonn (ZEF Bonn) - Germany, 7-10 June, 1999, Developments : $\eta$ rlant and Soil Sciences. Springer Netherlands, Dordrecht, pp. 718. https://doi.org/10.1007/978-94-017-2172-1_2

Damon, P.M., Bowden, B., Rose, T., Rengel, Z., 2014. Crop residue contributions to phosphorus pools in agricultural soils: A review. Soil Biology and Biochemistry 74, 127137. https://doi.org/10.1016/j.soilbio.2014.03.003

Damour, G., Navas, M.L., Garnier, E., 2018. A revised trait-based framework for agroecosystems including decision rules. Journal of Applied Ecology 55, 12-24. https://doi.org/10.1111/1365-2664.12986 
Dawson, I.K., Park, S.E., Attwood, S.J., Jamnadass, R., Powell, W., Sunderland, T., Carsan, S., 2019. Contributions of biodiversity to the sustainable intensification of food production. Global Food Security 21, 23-37. https://doi.org/10.1016/j.gfs.2019.07.002

De Deyn, G.B., Raaijmakers, C.E., Van Ruijven, J., Berendse, F., Van Der Putten, W.H., 2004. Plant species identity and diversity effects on different trophic levels of nematodes in the soil food web. Oikos 106, 576-586. https://doi.org/10.1111/j.0030-1299.2004.13265.x de Vries, F.T. de, Thébault, E., Liiri, M., Birkhofer, K., T.`afouli, M.A., Bjørnlund, L., Jørgensen, H.B., Brady, M.V., Christensen, S., Ruiter, P.(' de d’Hertefeldt, T., Frouz, J., Hedlund, K., Hemerik, L., Hol, W.H.G., Hotes, S., I Ic+tir.ıer, S.R., Setälä, H., Sgardelis, S.P., Uteseny, K., Putten, W.H. van der, Wolters, V., 3ardgett, R.D., 2013. Soil food web properties explain ecosystem services acro s Zuropean land use systems. PNAS 110, 14296-14301. https://doi.org/10.1073/r _.. s.1.205198110

de Vries, W., Breeuwsma, A., 198\% The relation between soil acidification and element cycling. Water Air Soil Pollut 35, 2 53-310. https://doi.org/10.1007/BF00290937

Deberdt, P., Fernandes, P., 20:7. Agroecological management of bacterial wilt of tomato in Martinique, in: Agroemluri al Crop Protection / Deguine Jean-Philippe (Ed.), Gloanec Caroline (Ed.), Lauı nt rhilippe (Ed.), Ratnadass Alain (Ed.), Aubertot Jean-Noel (Ed.). Springer; Ed. Quae, Dordrecht, pp. 120-124.

Díaz, S., Settele, J., Brondízio, E., Ngo, H., Guèze, M., Agard, J., Arneth, A., Balvanera, P., Brauman, K., Butchart, S., Chan, K., Garibaldi, L., Ichii, K., Liu, J., Subrmanian, S., Midgley, G., Miloslavich, P., Molnár, Z., Obura, D., Pfaff, A., Polasky, S., Purvis, A., Razzaque, J., Reyers, B., Chowdhury, R., Shin, Y., Visseren-Hamakers, I., Wilis, K., Zayas, C., 2020. Summary for policymakers of the global assessment report on 
biodiversity and ecosystem services of the Intergovernmental Science-Policy Platform on Biodiversity and Ecosystem Services.

Drinkwater, L.E., Wagoner, P., Sarrantonio, M., 1998. Legume-based cropping systems have reduced carbon and nitrogen losses. Nature 396, 262-265. https://doi.org/10.1038/24376

Duchene, O., Vian, J.-F., Celette, F., 2017. Intercropping with legume for agroecological cropping systems: Complementarity and facilitation processes and the importance of soil microorganisms. A review. Agriculture, Ecosystems \& Environment 240, 148-161. https://doi.org/10.1016/j.agee.2017.02.019

Dybzinski, R., Fargione, J.E., Zak, D.R., Fornara, D., Tï. nan, D., 2008. Soil fertility increases with plant species diversity in a long-term biodive Ity $_{\text {ity }}$ experiment. Oecologia 158, 85-93. https://doi.org/10.1007/s00442-008-1123-x

Ferris, H., Bongers, T., de Goede, R.G.I: 2001. A framework for soil food web diagnostics: extension of the nematode faunal : nalysis concept. Applied Soil Ecology 18, 13-29. https://doi.org/10.1016/S0929-129'(r)1)00152-4

Freschet, G., Roumet, C., Con nas, L., Weemstra, M., Bengough, A., Rewald, B., Bardgett, R., Deyn, G.B., Johnson, ע., Kıimešová, J., Lukac, M., Mccormack, M., Meier, I., Pagès, L., Poorter, H., Prieto, I., Vurzburger, N., Zadworny, M., Bagniewska-Zadworna, A., Stokes, A., 2021. Root traits as drivers of plant and ecosystem functioning: current understanding, pitfalls and future research needs. New Phytologist, in press.

Freschet, G.T., Roumet, C., 2017. Sampling roots to capture plant and soil functions. Funct Ecol 31, 1506-1518. https://doi.org/10.1111/1365-2435.12883

Fujii, K., Shibata, M., Kitajima, K., Ichie, T., Kitayama, K., Turner, B.L., 2018. Plant--soil interactions maintain biodiversity and functions of tropical forest ecosystems. Ecol Res 33, 149-160. https://doi.org/10.1007/s11284-017-1511-y 
Garnier, E., Navas, M.-L., 2012. A trait-based approach to comparative functional plant ecology: concepts, methods and applications for agroecology. A review. Agron. Sustain. Dev. 32, 365-399. https://doi.org/10.1007/s13593-011-0036-y

Goulding, K.W.T., 2016. Soil acidification and the importance of liming agricultural soils with particular reference to the United Kingdom. Soil Use Manag 32, 390-399. https://doi.org/10.1111/sum.12270

Han, W.X., Fang, J.Y., Reich, P.B., Woodward, F.I., Wang, ``H., 2011. Biogeography and variability of eleven mineral elements in plant leaves acrc ss $g$ adients of climate, soil and plant functional type in China. Eccios: Letters 14, 788-796. https://doi.org/10.1111/j.1461-0248.2011.01641.x

Hedges, L.V., Gurevitch, J., Curtis, P.S., 199! . Il e Meta-Analysis of Response Ratios in Experimental Ecology. Ecology 80, $1^{1}$ 50- 115ú. https://doi.org/10.2307/177062

Hinsinger, P., Plassard, C., Tang, C., Ja: ${ }^{\cdot 1}$ lard, B., 2003. Origins of root-mediated pH changes in the rhizosphere and their re noi s to environmental constraints: A review. Plant and Soil 248, 43-59. https://doi.. rg/1u.1023/A:1022371130939

Hobbie, S.E., 2015. Pli il pecies effects on nutrient cycling: revisiting litter feedbacks. Trends in Ecology \& 七/olution 30, 357-363. https://doi.org/10.1016/j.tree.2015.03.015

Hou, E., Luo, Y., Kuang, Y., Chen, C., Lu, X., Jiang, L., Luo, X., Wen, D., 2020. Global meta-analysis shows pervasive phosphorus limitation of aboveground plant production in natural terrestrial ecosystems. Nature Communications 11, 637. https://doi.org/10.1038/s41467-020-14492-w

Isbell, F., Gonzalez, A., Loreau, M., Cowles, J., Díaz, S., Hector, A., Mace, G.M., Wardle, D.A., O’Connor, M.I., Duffy, J.E., Turnbull, L.A., Thompson, P.L., Larigauderie, A., 
2017. Linking the influence and dependence of people on biodiversity across scales. Nature 546, 65-72. https://doi.org/10.1038/nature22899

Kirkby, C.A., Kirkegaard, J.A., Richardson, A.E., Wade, L.J., Blanchard, C., Batten, G., 2011. Stable soil organic matter: A comparison of C:N:P:S ratios in Australian and other world soils. Geoderma 163, 197-208. https://doi.org/10.1016/j.geoderma.2011.04.010

Kruse, J., Abraham, M., Amelung, W., Baum, C., Bol, R., Kühn, O., Lewandowski, H., Niederberger, J., Oelmann, Y., Rüger, C., Santner, J., Siebe.`. M., Siebers, N., Spohn, M., Vestergren, J., Vogts, A., Leinweber, P., 2015. Innovat, ve 1 lethods in soil phosphorus research: A review. Journal of Plant Nutritior : $n r^{\prime}$ Soil Science 178, 43-88. https://doi.org/10.1002/jpln.201400327

Lambers, H., Raven, J.A., Shaver, G.R., Si i`n. S.E., 2008. Plant nutrient-acquisition strategies change with soil age. Trfads in Ecology \& Evolution 23, 95-103. https://doi.org/10.1016/j.tree.2007.10.008

Latati, M., Bargaz, A., Belarbi, P L``ali, M., Benlahrech, S., Tellah, S., Kaci, G., Drevon, J.J., Ounane, S.M., 2016. The intercropping common bean with maize improves the rhizobial efficiency, reso re use and grain yield under low phosphorus availability. European Journal ot ‘' gronomy 72, 80-90. https://doi.org/10.1016/j.eja.2015.09.015

Lefcheck, J.S., Byrnes, J.E.K., Isbell, F., Gamfeldt, L., Griffin, J.N., Eisenhauer, N., Hensel, M.J.S., Hector, A., Cardinale, B.J., Duffy, J.E., 2015. Biodiversity enhances ecosystem multifunctionality across trophic levels and habitats. Nature Communications 6, 6936. https://doi.org/10.1038/ncomms7936

Maire, V., Wright, I.J., Prentice, I.C., Batjes, N.H., Bhaskar, R., Bodegom, P.M. van, Cornwell, W.K., Ellsworth, D., Niinemets, Ü., Ordonez, A., Reich, P.B., Santiago, L.S., 
2015. Global effects of soil and climate on leaf photosynthetic traits and rates. Global Ecology and Biogeography 24, 706-717. https://doi.org/10.1111/geb.12296

Manlay, R.J., Feller, C., Swift, M.J., 2007. Historical evolution of soil organic matter concepts and their relationships with the fertility and sustainability of cropping systems. $\begin{array}{lllll}\text { Agriculture, } & \text { Ecosystems } & \& & \text { Environment } & 119,\end{array}$ https://doi.org/10.1016/j.agee.2006.07.011

Manzoni, S., Jackson, R.B., Trofymow, J.A., Porporato, A., $2 \mathfrak{i}^{n} 8$. The Global Stoichiometry of Litter Nitrogen Mineralization. S ienı e 321, 684-686. https://doi.org/10.1126/science.1159792

Martin, A.R., Isaac, M.E., 2015. REVIEW: Plant sr.ctional traits in agroecosystems: a blueprint for research. Journal of $t$ pplied Ecology 52, 1425-1435. https://doi.org/10.1111/1365-2664.12₹26

Neves, M.S.A.C., Souto, M.R.S., Tu.h, I.V., Victal, S.M.A., Drumond, M.C., Rangel, A.O.S.S., 2008. Spectropho ${ }^{+\wedge m^{+*}}{ }^{\text {c }} \mathrm{c}$ flow system using vanadomolybdophosphate detection chemistry and a liquid waveguide capillary cell for the determination of phosphate with improvea sitivity in surface and ground water samples. Talanta, 14th International Confer 'ce on Flow Injection Analysis and Related Techniques 77, 527-532. https://doi.org/10.1016/j.talanta.2008.03.014

Olsen, S.R. (Sterling R., 1954. Estimation of available phosphorus in soils by extraction with sodium bicarbonate. Washington, D.C. : U.S. Dept. of Agriculture.

Petit-Aldana, J., Rahman, M.M., Parraguirre-Lezama, C., Infante-Cruz, A., Romero-Arenas, O., 2019. Litter Decomposition Process in Coffee Agroforestry Systems. Journal of $\begin{array}{llll}\text { Forest } \quad \text { and } & \text { Environmental }\end{array}$ https://doi.org/10.7747/JFES.2019.35.2.121 
Plassard, C., Robin, A., Cadre, E.L., Marsden, C., Trap, J., Herrmann, L., Waithaisong, K., Lesueur, D., Blanchard, E., Chapuis-Lardy, L., Hinsinger, P., 2015. Ameliorer la biodisponibilite du phosphore: comment valoriser les competences des plantes et les mecanismes biologiques du sol ? Innovations Agronomiques 43, 115-138.

Raminoarison, M., Razafimbelo, T., Rakotoson, T., Becquer, T., Blanchart, E., Trap, J., 2020. Multiple-nutrient limitation of upland rainfed rice in ferralsols: a greenhouse nutrientomission trial. Journal of Plant Nrtrition 43, 270-284. https://doi.org/10.1080/01904167.2019.1676906

Ranoarisoa, M.P., Morel, C., Andriamananjara, A., Jo iri’n, C., Bernard, L., Becquer, T., Rabeharisoa, L., Rahajaharilaza, K., Plassard, C., 3lan hart, E., Trap, J., 2018. Effects of a bacterivorous nematode on rice $32 \mathrm{P}$ uptak c ad root architecture in a high $\mathrm{P}$-sorbing ferrallitic soil. Soil Biole ${ }_{0}$ and Biochemistry 122, 39-49. https://doi.org/10.1016/j.soilbio.2018.04.`’2

Ranoarisoa, M.P., Trap, J., Pablo, A-1 ., Dezette, D., Plassard, C., 2020. Micro-food web interactions involving bacte ia, nematodes, and mycorrhiza enhance tree $\mathrm{P}$ nutrition in a high P-sorbing soil ame ^dea with phytate. Soil Biology and Biochemistry 143, 107728. https://doi.org/10.1 '1૮!is jilbio.2020.107728

Rao, A.S., Reddy, K.S., Takkar, P.N., 1997. Malachite green method compared to ascorbic acid for estimating small amounts of phosphorus in water, $0.01 \mathrm{M}$ calcium chloride, and olsen soil extracts. Communications in Soil Science and Plant Analysis 28, 589-601. https://doi.org/10.1080/00103629709369813

Ratnadass, A., Fernandes, P., Avelino, J., Habib, R., 2012. Plant species diversity for sustainable management of crop pests and diseases in agroecosystems: a review. Agron. Sustain. Dev. 32, 273-303. https://doi.org/10.1007/s13593-011-0022-4 
Renard, D., Tilman, D., 2019. National food production stabilized by crop diversity. Nature 571, 257-260. https://doi.org/10.1038/s41586-019-1316-y

Ripoche, A., Blanchard, E., Trap, J., Sauvadet, M., Autfray, P., Randriamanantsoa, R., Rabary, B., 2019. Does an increase in plant diversity enhance agroecosystem services? Case study in rainfed rice based cropping systems in Madagascar. Presented at the 6th International SYmposium for Farming Systems Design, Universidad de la República Uruguay, Montevideo, Uruguay.

Ritz, K., Trudgill, D.L., 1999. Utility of nematode comm nit analysis as an integrated

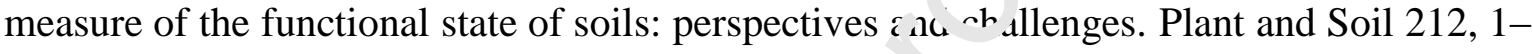
11. https://doi.org/10.1023/A:1004673027625

Sauvadet, M., den Meersche, K.V., Allinne, C., F ay F., de Melo Virginio Filho, E., Chauvat, M., Becquer, T., Tixier, P., Harmand J.- 1., 2019. Shade trees have higher impact on soil nutrient availability and food $w^{h}$ in organic than conventional coffee agroforestry. Science of The foral Environment 649, 1065-1074. https://doi.org/10.1016/j.scit steı.2018.08.291

Sauvadet, M., Saj, S., Freschr, G.T., Essobo, J.-D., Enock, S., Becquer, T., Tixier, P.,

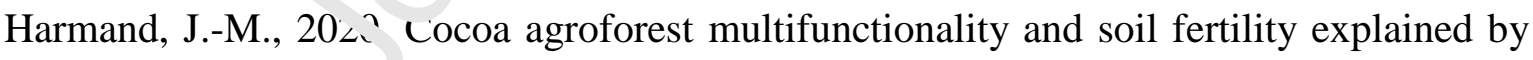
shade tree litter traits. Journal of Applied Ecology 57, 476-487. https://doi.org/10.1111/1365-2664.13560

Sawers, R.J.H., Svane, S.F., Quan, C., Grønlund, M., Wozniak, B., Gebreselassie, M.-N., González-Muñoz, E., Chávez Montes, R.A., Baxter, I., Goudet, J., Jakobsen, I., Paszkowski, U., 2017. Phosphorus acquisition efficiency in arbuscular mycorrhizal maize is correlated with the abundance of root-external hyphae and the accumulation of 
transcripts encoding PHT1 phosphate transporters. New Phytol. 214, 632-643. https://doi.org/10.1111/nph.14403

Seinhorst, J.W., 1950. De betekenis van de toestand van de grond voor het optreden van aantasting door het stengelaaltje (Ditylenchus dipsaci (KÜHN) Filipjev). Tijdschrift Over Plantenziekten 56, 289-348. https://doi.org/10.1007/BF01989990

Shipley, B., 2009. Confirmatory path analysis in a generalized multilevel context. Ecology 90, 363-368. https://doi.org/10.1890/08-1034.1

Stumpe, J.M., Vlek, P.L.G., 1991. Acidification Induced hv n:iferent Nitrogen Sources in Columns of Selected Tropical Soils. Soil Science Sou ety of America Journal 55, 145-151. https://doi.org/10.2136/sssaj1991.0361599500550七^1⁄,J26x

Tiemann, L.K., Grandy, A.S., Atkinson, E.E., M. Mir-Spiotta, E., McDaniel, M.D., 2015. Crop rotational diversity enhances be w ground communities and functions in an agroecosystem. Ecology Letters 18, ; $1-771$. https://doi.org/10.1111/ele.12453

Tixier, P., Lavigne, C., Alvarez.S., ' jauquier, A., Blanchard, M., Ripoche, A., Achard, R., 2011. Model evaluation of co : erops, application to eleven species for banana cropping systems. Europ an Journal of Agronomy 34, 53-61. https://doi.org/10.1016, j.eja.2010.10.004

Trap, J., Bonkowski, M., Plassard, C., Villenave, C., Blanchart, E., 2016. Ecological importance of soil bacterivores for ecosystem functions. Plant Soil 1-24. https://doi.org/10.1007/s11104-015-2671-6

Tscharntke, T., Clough, Y., Bhagwat, S.A., Buchori, D., Faust, H., Hertel, D., Hölscher, D., Juhrbandt, J., Kessler, M., Perfecto, I., Scherber, C., Schroth, G., Veldkamp, E., Wanger, T.C., 2011. Multifunctional shade-tree management in tropical agroforestry landscapes - a 
review. Journal of Applied Ecology 48, 619-629. https://doi.org/10.1111/j.13652664.2010.01939.x

van Breemen, N., Mulder, J., Driscoll, C.T., 1983. Acidification and alkalinization of soils. Plant Soil 75, 283-308. https://doi.org/10.1007/BF02369968

van den Hoogen, J., Geisen, S., Routh, D., Ferris, H., Traunspurger, W., Wardle, D.A., de Goede, R.G.M., Adams, B.J., Ahmad, W., Andriuzzi, W.S., Bardgett, R.D., Bonkowski, M., Campos-Herrera, R., Cares, J.E., Caruso, T., de Brito Caixeta, L., Chen, X., Costa, S.R., Creamer, R., Mauro da Cunha Castro, J., Dam, M., . )iig 1, D., Escuer, M., Griffiths, B.S., Gutiérrez, C., Hohberg, K., Kalinkina, D., Karc'o,, D , Kergunteuil, A., Korthals, G., Krashevska, V., Kudrin, A.A., Li, Q., Liang, W., ' Tagi ton, M., Marais, M., Martín, J.A.R., Matveeva, E., Mayad, E.H., Mulder, C., Mul'il P., Neilson, R., Nguyen, T.A.D., Nielsen, U.N., Okada, H., Rius, J.E.P., Pan, K., ₹ ne ר V., Pellissier, L., Carlos Pereira da Silva, J., Pitteloud, C., Powers, T.O., Powers, K., ?uist, C.W., Rasmann, S., Moreno, S.S., Scheu, S., Setälä, H., Sushchuk, A., Tiu ıc 、 A.V., Trap, J., van der Putten, W., Vestergård, M., Villenave, C., Waeyenberge, L., Wall, D.H., Wilschut, R., Wright, D.G., Yang, J., Crowther, T.W., 2019. Soli nematode abundance and functional group composition at a global scale. Nature 5 '2, , 94-198. https://doi.org/10.1038/s41586-019-1418-6

Violle, C., Navas, M.-L., Vile, D., Kazakou, E., Fortunel, C., Hummel, I., Garnier, E., 2007. Let the concept of trait be functional! Oikos 116, 882-892. https://doi.org/10.1111/j.00301299.2007.15559.x

Waithaisong, K., Robin, A., Mareschal, L., Bouillet, J.-P., Laclau, J.-P., Deleporte, P., Gonçalves, J.L. de M., Harmand, J.-M., Plassard, C., 2020. Introducing N2-fixing trees (Acacia mangium) in eucalypt plantations rapidly modifies the pools of organic $\mathrm{P}$ and low 
molecular weight organic acids in tropical soils. Science of The Total Environment 742, 140535. https://doi.org/10.1016/j.scitotenv.2020.140535

Walker, T.W., Syers, J.K., 1976. The fate of phosphorus during pedogenesis. Geoderma 15, 1-19. https://doi.org/10.1016/0016-7061(76)90066-5

Wardle, D.A., Yeates, G.W., Williamson, W., Bonner, K.I., 2003. The response of a three trophic level soil food web to the identity and diversity of plant species and functional groups. Oikos 102, 45-56. https://doi.org/10.1034/j.1600-0־``.2003.12481.x

Wood, S.A., Karp, D.S., DeClerck, F., Kremen, C., Naeem S., ralm, C.A., 2015. Functional traits in agriculture: agrobiodiversity and ecosystem ervices. Trends Ecol. Evol. (Amst.) 30, 531-539. https://doi.org/10.1016/j.tree.2015.06. ${ }^{21}$ '

Yeates, G.W., 2003. Nematodes as soil indic atc c runctional and biodiversity aspects. Biol Fertil Soils 37, 199-210. https://doi.o_ ־/1 J.1007/s00374-003-0586-5

Yeates, G.W., Bongers, T., De Gorde, R.G.M., Freckman, D.W., Georgieva, S.S., 1993. Feeding Habits in Soil Nemat st Families and Genera-An Outline for Soil Ecologists. J Nematol 25, 315-331. 

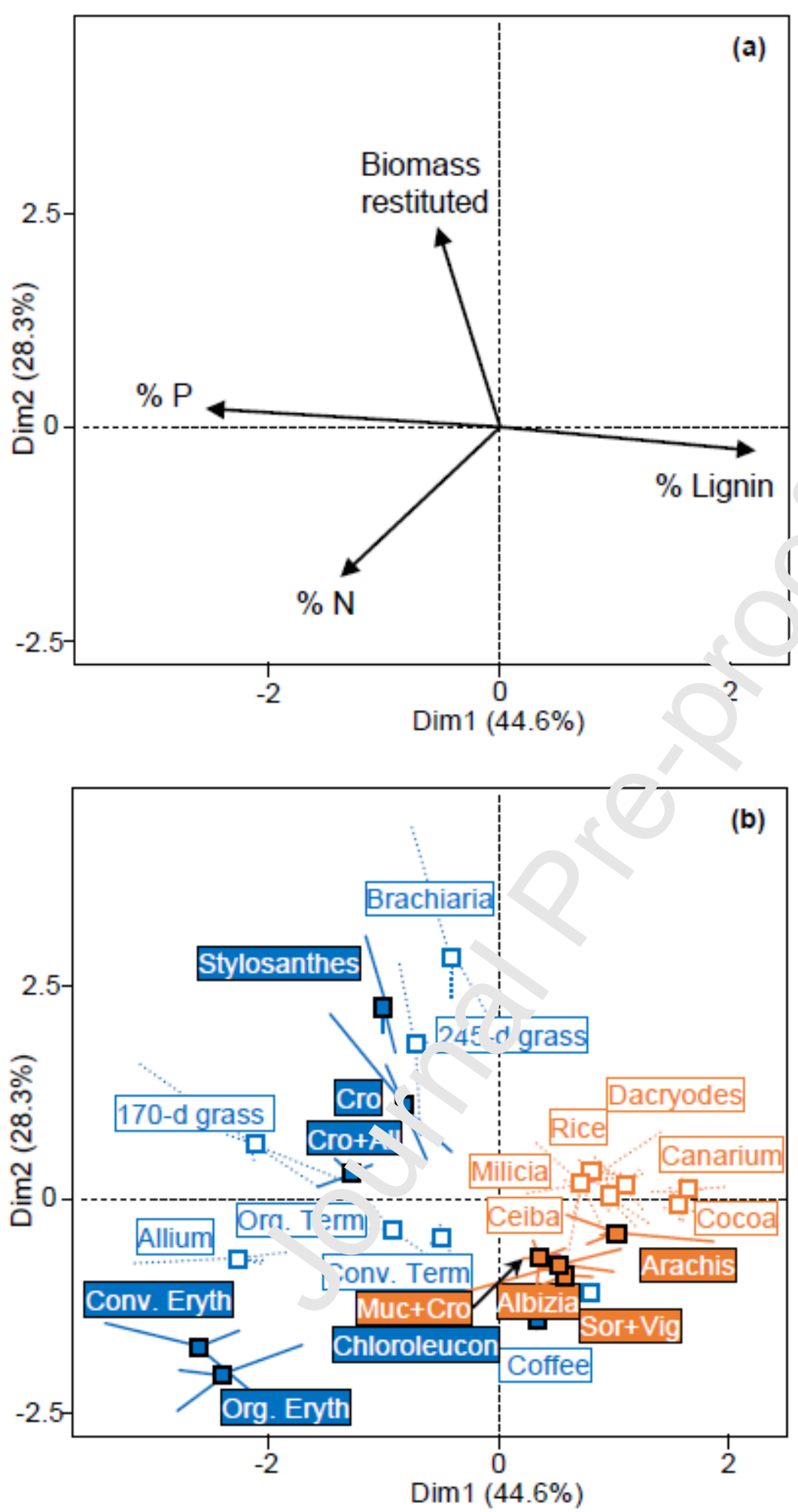

Fig. 1: Principal component analysis of plant community traits (a) variables and (b) individual factor map in the six experimental sites. Plant communities studied on Ferralsols and on volcanic soils are represented in orange and blue, respectively. Full and empty symbols indicate plant communities with and without legumes, respectively. Ferralsols: Rice and 
Cocoa sites; Volcanic soils: Tomato, Banana, Organic and Conventional Coffee sites. For a full description of the plant communities, see Table 1. Cro: Crotalaria spectabilis; Cro+All: C. spectabilis + Allium fistulosum; Muc+Cro: Mucuna cochinchinensis + C. spectabilis; Sor+Vig: Sorghum bicolor +Vigna unguiculate; Conv. Eryth: Erythrina poepiggiana + Coffea arabica in conventional system; Org. Eryth: E. poepiggiana + C. arabica in organic system; Conv. Term: Terminalia amazonia + C. arabica in conventional system; Org. Term: T. amazonia + C. arabica in organic system.
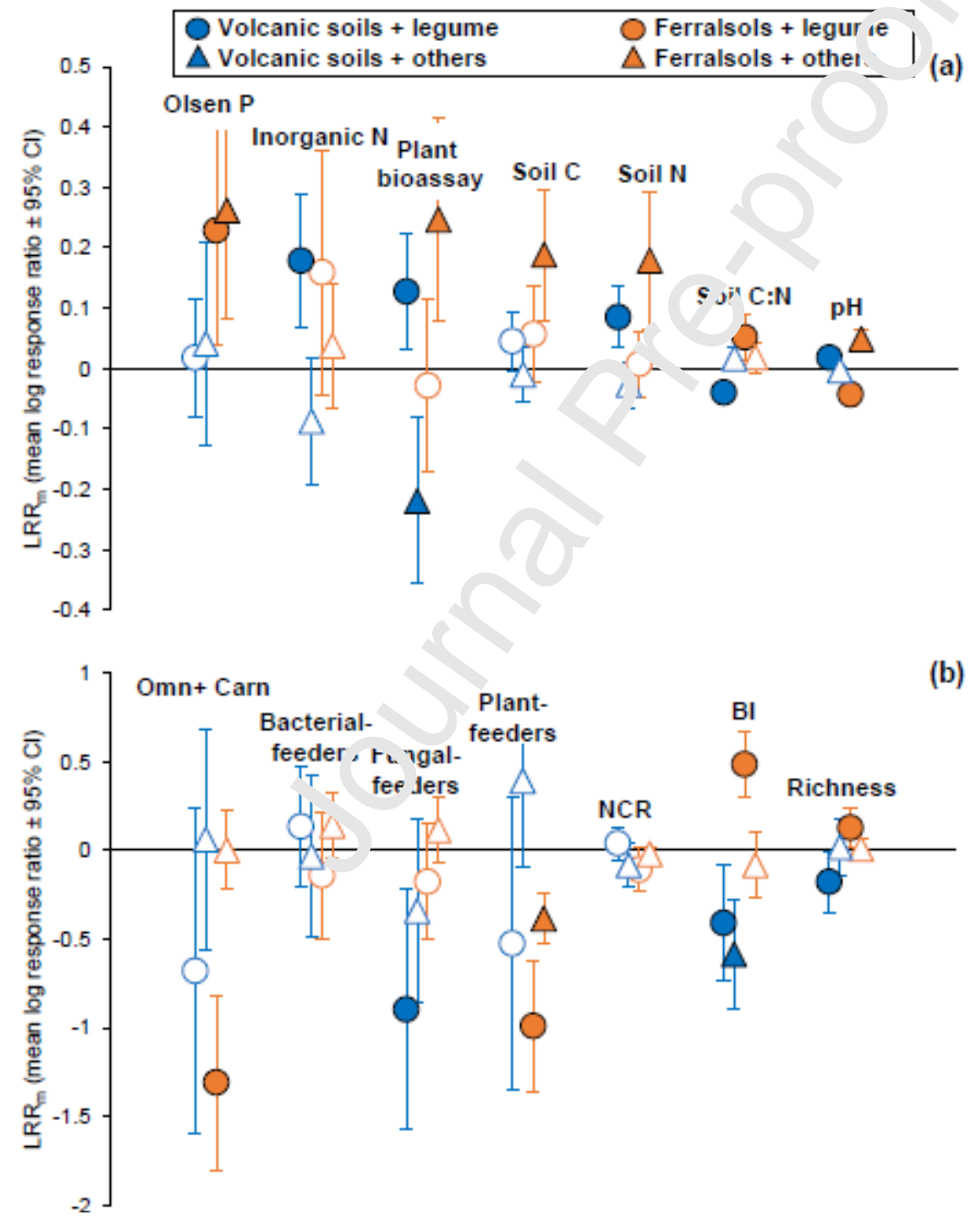

Fig. 2: Plant diversification impacts on soil fertility (a) and nematode indices (b). Data were calculated as mean log response ratio $\left(\mathrm{LRR}_{\mathrm{m}}\right)$ of diversification as compared to the reference 
treatment of each site. Full and empty symbols indicate significant and non-significant effects, respectively. Vertical bars correspond to $95 \%$ confidence intervals. Ferralsols: Rice and Cocoa sites; Volcanic soils: Tomato, Banana, Organic and Conventional Coffee sites. For a full description of reference treatments, see Table 2.

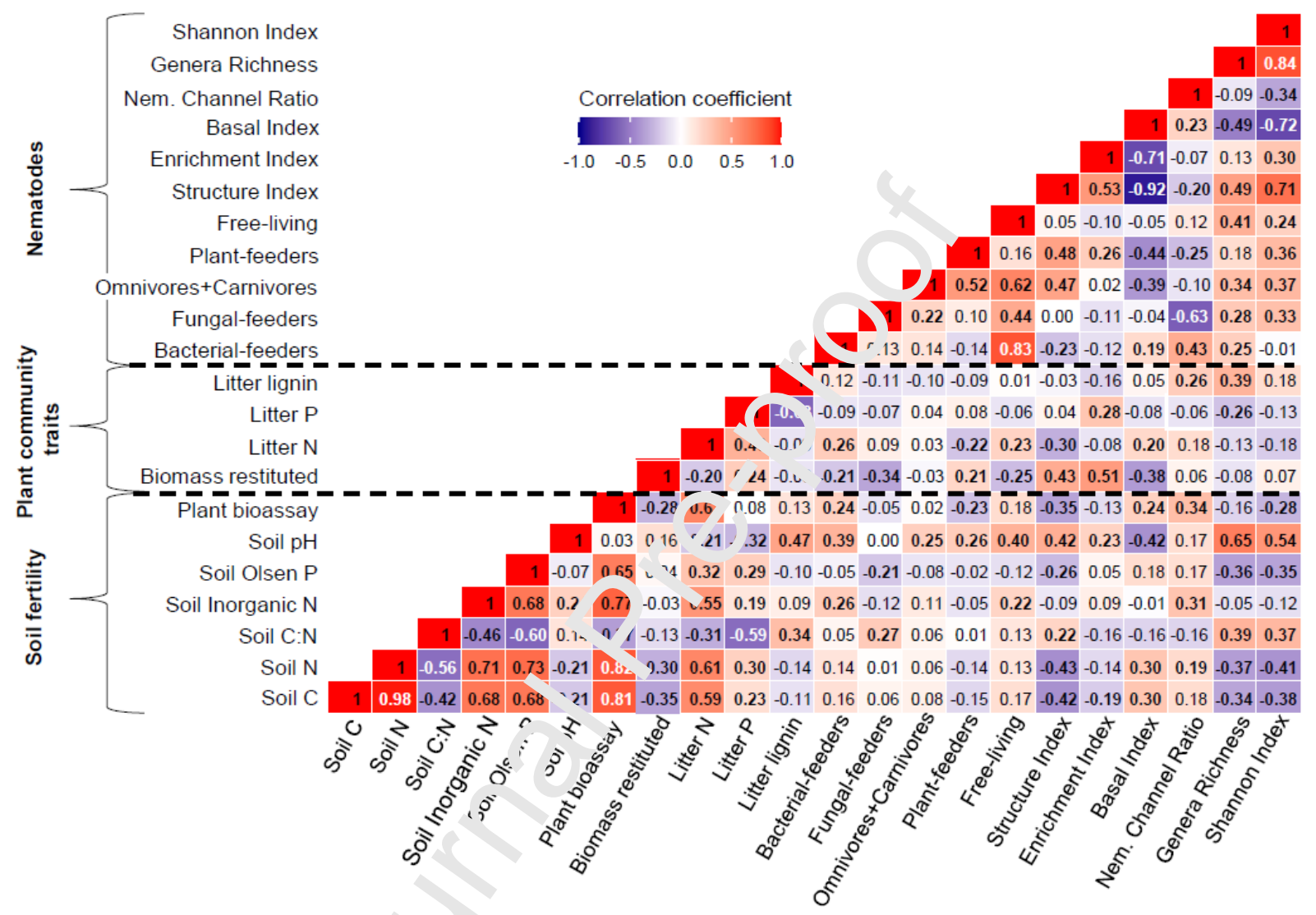

Fig. 3: Pearson corre'atı $n$, oefficient matrices of soil fertility, plant community traits and nematode indices on tıe whole dataset $(n=142)$. Correlations were corrected for multiple comparisons with the Benjamini-Hochberg method. Significant correlations ( $\mathrm{p}$-value $<0.05$ ) are written in boldface. 

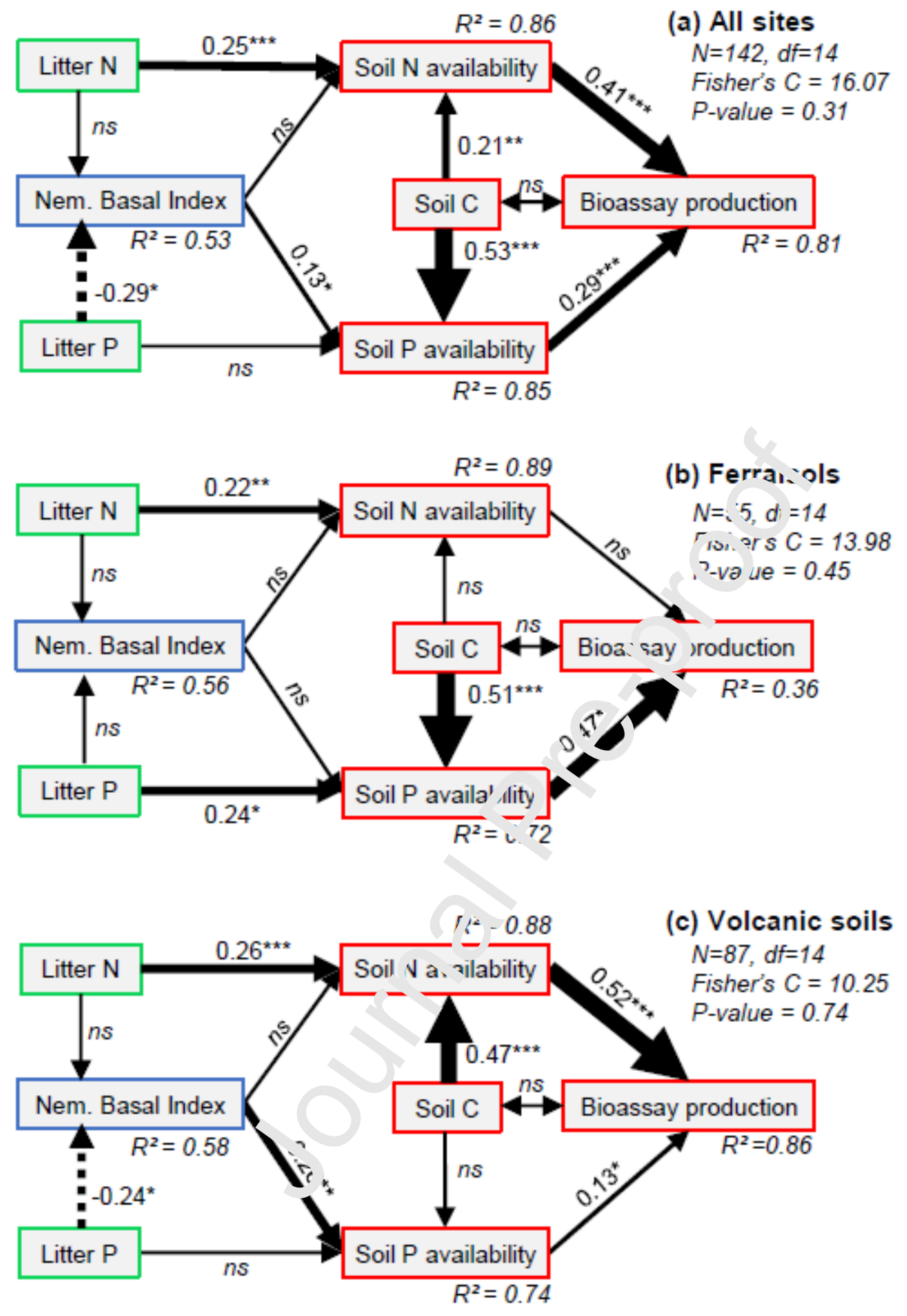

Fig. 4: Piecewise structural equation models on plant community traits impacts on soil fertility for all sites (a), sites on Ferralsols (b), and sites on volcanic soils (c). Variables of plant community traits, nematodes, and soil fertility are represented in green, blue and red, respectively. The numbers on the arrows are path coefficients; dashed line arrows indicate negative effects, and double arrows covariation relationships. The $\mathrm{R}^{2}$ value represents the 
proportion of total variance explained by the model. Asterisks represent the level of significance of the paths; $*$ stands for $\mathrm{P}$-values $<0.05$; ** for $\mathrm{P}$-values $<0.01$; *** for $\mathrm{P}$ values < 0.001 Ferralsols: Rice and Cocoa sites; Volcanic soils: Tomato, Banana, Organic and Conventional Coffee sites. The analyses were performed on standardized normally distributed data.

Table 1. Sites presentation. Legume species are in bold. Coffee site tested plant diversification impacts for organic and conventional systems.

\begin{tabular}{|c|c|c|c|c|c|}
\hline & \multicolumn{5}{|c|}{ Experimental sites } \\
\hline & Tomato & Banana & Rice & $\begin{array}{l}\text { Coffee (organic } \\
\& \text { conventional) }\end{array}$ & Cocoa \\
\hline Country & $\begin{array}{c}\text { Martinique } \\
\text { (West Indies) }\end{array}$ & $\begin{array}{l}\text { Martiniq } \\
\text { ue (West } \\
\text { Indies) }\end{array}$ & Mad sze scur & Costa Rica & $\begin{array}{l}\text { Camero } \\
\text { on }\end{array}$ \\
\hline Position & $\begin{array}{c}14^{\circ} 66 \mathrm{~N}, 61^{\circ} 00 \\
\mathrm{~W}\end{array}$ & $\begin{array}{c}14^{\circ} 66 \\
\mathrm{~N} \\
61^{\circ} \mathrm{j0} \\
\mathrm{h}\end{array}$ & $\begin{array}{l}1033 \mathrm{~S} \\
+6^{\circ} 25 \mathrm{E}\end{array}$ & $9^{\circ} 53 \mathrm{~N}, 83^{\circ} 40 \mathrm{~W}$ & $\begin{array}{l}4^{\circ} 30 \mathrm{~N} \\
11^{\circ} 10 \mathrm{E}\end{array}$ \\
\hline Altitude & $54 \mathrm{~m}$ a.s.1 & $\begin{array}{l}54 \mathrm{~m} \\
\text { a.. } 1\end{array}$ & $930 \mathrm{~m}$ a.s.1 & $600 \mathrm{~m}$ a.s.l & $\begin{array}{c}400-550 \\
\text { m a.s. } 1\end{array}$ \\
\hline $\begin{array}{l}\text { Annual } \\
\text { Precipitation }\end{array}$ & $2000 \mathrm{~mm} \mathrm{y}^{-1}$ & $\begin{array}{l}21,00 \\
\mathrm{~mm} \mathrm{y}^{-1}\end{array}$ & $1330 \mathrm{~mm} \mathrm{y}^{-1}$ & $2915 \mathrm{~mm} \mathrm{y}^{-1}$ & $\begin{array}{c}1300- \\
1400 \\
\mathrm{~mm} \mathrm{y}^{-1}\end{array}$ \\
\hline $\begin{array}{l}\text { Average } \\
\text { temperature }\end{array}$ & $25^{\circ} \mathrm{C}$ & $25^{\circ} \mathrm{C}$ & $24^{\circ} \mathrm{C}$ & $22^{\circ} \mathrm{C}$ & $25^{\circ} \mathrm{C}$ \\
\hline $\begin{array}{l}\text { Soil } \\
\text { information }\end{array}$ & Nitis נI ?lay & $\begin{array}{l}\text { Nitisol } \\
\text { Clay }\end{array}$ & $\begin{array}{c}\text { Ferralsol } \\
\text { Sandy clay - } \\
\text { loam }\end{array}$ & $\begin{array}{c}\text { Acrisol - } \\
\text { Cambisol } \\
\text { Loam - clay loam }\end{array}$ & $\begin{array}{c}\text { Ferralsol } \\
\text { Sandy } \\
\text { loam }\end{array}$ \\
\hline Soil type & Volcanic soil & $\begin{array}{l}\text { Volcani } \\
\text { c soil }\end{array}$ & Ferralsol & Volcanic soil & Ferralsol \\
\hline Main crop & Tomato & Banana & Rice & Coffee & Cocoa \\
\hline Fertilization & $\begin{array}{c}\text { None to } 138 \mathrm{~kg} \\
\mathrm{~N} \mathrm{ha}^{-1}, 138 \mathrm{~kg} \mathrm{P} \\
\mathrm{ha}^{-1}, 276 \mathrm{~kg} \mathrm{~K} \\
\text { ha }^{-1}\end{array}$ & $\begin{array}{l}205 \mathrm{~kg} \\
\mathrm{~N} \mathrm{ha}^{-1}\end{array}$ & $\begin{array}{l}5 \mathrm{t} \mathrm{ha}^{-1} \\
\text { manure }\end{array}$ & $\begin{array}{c}\text { Organic: } 5 \mathrm{t} \mathrm{ha}^{-1} \\
\text { coffee pulp } \\
\text { Conventional: } \\
150 \mathrm{~kg} \mathrm{~N} \mathrm{ha}^{-1}, 10 \\
\mathrm{~kg} \mathrm{P} \mathrm{ha}^{-1}, 75 \mathrm{~kg} \mathrm{~K}^{-1} \\
\mathrm{ha}^{-1}\end{array}$ & None \\
\hline $\begin{array}{l}\text { Diversificatio } \\
\text { n mode }\end{array}$ & Rotation & Rotation & Rotation & Agroforestry & $\begin{array}{c}\text { Agrofor } \\
\text { estry }\end{array}$ \\
\hline $\begin{array}{l}\text { Reference } \\
\text { treatment }\end{array}$ & $\begin{array}{l}\text { 1. 170-days } \\
\text { grass* }\end{array}$ & $\begin{array}{l}\text { 1. } 245- \\
\text { days } \\
\text { grass* }\end{array}$ & 1. Rice & $\begin{array}{l}\text { 1. Unshaded } \\
\text { coffee }\end{array}$ & $\begin{array}{c}1 . \\
\text { Unshade } \\
\text { d cocoa }\end{array}$ \\
\hline
\end{tabular}




\begin{tabular}{|c|c|c|c|c|c|}
\hline $\begin{array}{l}\text { Plant } \\
\text { communities } \\
\text { tested for } \\
\text { diversification }\end{array}$ & $\begin{array}{l}\text { 2. Allium } \\
\text { fistolusum } \\
\text { 3. Crotalaria } \\
\text { spectabilis } \\
\text { 4. C. spectabilis } \\
\text { + Allium } \\
\text { fistolusum }\end{array}$ & $\begin{array}{c}2 . \\
\text { Brachia } \\
\text { ria } \\
\text { decumbe } \\
n s \\
3 . \\
\text { Stylosan } \\
\text { thes } \\
\text { guianen } \\
\text { sis }\end{array}$ & $\begin{array}{c}\text { 2. Arachis } \\
\text { hypogaea } \\
\text { 3. Mucuna } \\
\text { cochinchinen } \\
\text { sis+ } \\
\text { C.spectabilis } \\
\text { 4. Sorghum } \\
\text { bicolor } \\
\text { +Vigna } \\
\text { unguiculata }\end{array}$ & $\begin{array}{l}\text { 2. Chloroleucon } \\
\text { eurycyclum** } \\
\text { 3. Erythrina } \\
\text { poepiggiana } \\
\text { 4. Terminalia } \\
\text { amazonia }\end{array}$ & $\begin{array}{c}2 . \\
\text { Albizia } \\
\text { adianthi } \\
\text { folia } \\
3 . \\
\text { Canariu } \\
m \\
\text { schweinf } \\
\text { urthii } \\
\text { 4. Ceiba } \\
\text { pentandr } \\
\text { a } \\
5 . \\
\text { Dacryod } \\
\text { es edulis } \\
6 . \\
\text { Milicia } \\
\text { excelsa }\end{array}$ \\
\hline $\begin{array}{l}\text { Year of } \\
\text { sampling }\end{array}$ & 2017 & 2018 & $2 n 18$ & 2017 & 2017 \\
\hline $\begin{array}{l}\text { Site age at } \\
\text { sampling }\end{array}$ & 1 year & 1 year & 3 yea"s & $>17$ years & $\begin{array}{l}>17 \\
\text { years }\end{array}$ \\
\hline $\begin{array}{l}\text { Numb. } \\
\text { Observations }\end{array}$ & 20 & 18 & 16 & $\begin{array}{l}49(28+ \\
21)\end{array}$ & 39 \\
\hline $\begin{array}{l}\text { Reference } \\
\text { publication }\end{array}$ & $\begin{array}{l}\text { Deberdt and } \\
\text { Fernandes } \\
(2017)\end{array}$ & $\begin{array}{c}\text { Tixie at } \\
\text { al. } \\
?(v i 1)\end{array}$ & $\begin{array}{c}\text { Ripoche et al. } \\
\text { (2019) }\end{array}$ & $\begin{array}{l}\text { Sauvadet et al. } \\
\text { (2019) }\end{array}$ & $\begin{array}{c}\text { Sauvade } \\
\text { t et al. } \\
(2020)\end{array}$ \\
\hline
\end{tabular}

Table 2. Soil fertility and ner. ato ' $\mathrm{e}$ indices of the reference site treatments.

\begin{tabular}{|c|c|c|c|c|c|c|}
\hline \multicolumn{7}{|c|}{ Experimental sites } \\
\hline$\circlearrowleft$ & Tomato & Banana & Rice & $\begin{array}{c}\text { Conv. } \\
\text { Coffe } \\
e\end{array}$ & $\begin{array}{l}\text { Org. } \\
\text { Coffee }\end{array}$ & Cocoa \\
\hline Soil type & $\begin{array}{l}\text { Volcani } \\
\text { c soil }\end{array}$ & $\begin{array}{l}\text { Volcani } \\
\text { c soil }\end{array}$ & $\begin{array}{c}\text { Ferrals } \\
\text { ol }\end{array}$ & $\begin{array}{l}\text { Volc } \\
\text { anic } \\
\text { soil }\end{array}$ & $\begin{array}{l}\text { Volcani } \\
\text { c soil }\end{array}$ & $\begin{array}{c}\text { Ferralso } \\
1\end{array}$ \\
\hline Reference Treatment & $\begin{array}{l}170- \\
\text { days } \\
\text { grass }\end{array}$ & $\begin{array}{l}245- \\
\text { days } \\
\text { grass }\end{array}$ & Rice & $\begin{array}{c}\text { Conv } \\
\cdot \\
\text { Unsh } \\
\text { aded } \\
\text { coffe } \\
\text { e }\end{array}$ & $\begin{array}{c}\text { Org. } \\
\text { Unshade } \\
\text { d } \\
\text { coffee }\end{array}$ & $\begin{array}{c}\text { Unshad } \\
\text { ed } \\
\text { cocoa }\end{array}$ \\
\hline \multicolumn{7}{|c|}{ Soil biochemistry } \\
\hline Soil C ( $g C \mathrm{~kg}^{-1}$ soil $)$ & $\begin{array}{c}20.1 \pm 1 . \\
1 \mathrm{bc}\end{array}$ & $\begin{array}{c}21.6 \pm 1 \\
4 \mathrm{~b}\end{array}$ & $\begin{array}{c}18.0 \pm 0 \\
.9 \mathrm{c}\end{array}$ & $\begin{array}{r}36.9 \pm \\
4.9 \mathrm{a}\end{array}$ & $\begin{array}{c}39.3 \pm 5.0 \\
\mathrm{a}\end{array}$ & $\begin{array}{c}15.4 \pm 5 . \\
3 \mathrm{c}\end{array}$ \\
\hline
\end{tabular}




\begin{tabular}{|c|c|c|c|c|c|c|}
\hline Soil $\mathbf{N}\left(g N k^{-1}\right.$ soil $)$ & $\begin{array}{c}1.9 \pm 0.1 \\
b\end{array}$ & $\begin{array}{c}2.0 \pm 0.1 \\
b\end{array}$ & $\begin{array}{l}1.3 \pm 0 \\
0 \mathrm{c}\end{array}$ & $\begin{array}{l}3.5 \pm 0 \\
.4 \mathrm{a}\end{array}$ & $\begin{array}{c}3.6 \pm 0.5 \\
\mathrm{a}\end{array}$ & $\begin{array}{c}1.2 \pm 0.4 \\
\mathrm{c}\end{array}$ \\
\hline Soil C:N ratio & $\begin{array}{l}10.9 \pm 0 . \\
3 \mathrm{~b}\end{array}$ & $\begin{array}{l}11.0 \pm 0 . \\
2 \mathrm{~b}\end{array}$ & $\begin{array}{c}13.6 \pm 0 \\
.5 \mathrm{a}\end{array}$ & $\begin{array}{l}10.6 \pm \\
0.3 \mathrm{~b}\end{array}$ & $\begin{array}{c}10.8 \pm 0.3 \\
b\end{array}$ & $\begin{array}{c}12.5 \pm 1 \\
1 \mathrm{a}\end{array}$ \\
\hline $\begin{array}{l}\text { Inorganic } \mathbf{N}\left(m g N \mathrm{~kg}^{-1}\right. \\
\text { soil) }\end{array}$ & $\begin{array}{c}7.1 \pm 0.9 \\
\mathrm{c}\end{array}$ & $\begin{array}{c}16.1 \pm 3 . \\
3 \mathrm{a}\end{array}$ & $\begin{array}{c}3.5 \pm 1 \\
6 \mathrm{~d}\end{array}$ & $\begin{array}{l}11.1 \pm \\
1.3 \mathrm{~b}\end{array}$ & $\begin{array}{c}20.8 \pm 3.6 \\
a\end{array}$ & $\begin{array}{c}10.7 \pm 3 \text {. } \\
7 \mathrm{bc}\end{array}$ \\
\hline Olsen P ( $m g P \mathrm{~kg}^{-1}$ soil $)$ & $\begin{array}{c}12.3 \pm 2 . \\
8 \mathrm{c}\end{array}$ & $\begin{array}{c}34.6 \pm 2 \\
6 \mathrm{a}\end{array}$ & $\begin{array}{c}4.4 \pm 0 \\
1 \mathrm{~d}\end{array}$ & $\begin{array}{l}26.7 \pm \\
5.0 \mathrm{~b}\end{array}$ & $\begin{array}{l}39.0 \pm 10 . \\
2 \mathrm{ab}\end{array}$ & $\begin{array}{l}8.0 \pm 4.8 \\
\quad \mathrm{~cd}\end{array}$ \\
\hline $\mathrm{pH} \mathrm{H_{2 } \mathrm { O }}$ & $\begin{array}{c}5.5 \pm 0.1 \\
\mathrm{c}\end{array}$ & $\begin{array}{c}6.1 \pm 0.0 \\
b\end{array}$ & $\begin{array}{l}5.5 \pm 0 . \\
0 \mathrm{c}\end{array}$ & $\begin{array}{l}5.0 \pm 0 \\
.1 \mathrm{~d}\end{array}$ & $\begin{array}{c}6.2 \pm 0.1 \\
b\end{array}$ & $\begin{array}{c}6.6 \pm 0.1 \\
\mathrm{a}\end{array}$ \\
\hline $\begin{array}{l}\text { Plant bioassay ( } g \text { DM } \\
\text { produced per plant) }\end{array}$ & $\begin{array}{c}0.9 \pm 0.2 \\
\mathrm{c}\end{array}$ & $\begin{array}{c}1.6 \pm 1.0 \\
b\end{array}$ & $\begin{array}{c}1.3 \pm 1 \\
3 \mathrm{bc}\end{array}$ & $\begin{array}{c}3.4 \pm 1 \\
.3 \mathrm{a}\end{array}$ & $\begin{array}{c}4.2 \pm 1.0 \\
\mathrm{a}\end{array}$ & $\begin{array}{c}1.5 \pm 0.5 \\
b\end{array}$ \\
\hline $\begin{array}{l}\text { Bacterial-feeders (ind } \mathrm{kg}^{-} \\
{ }_{1} \text { soil) }\end{array}$ & $\begin{array}{c}1696 \pm 9 \\
00 \mathrm{a}\end{array}$ & $\begin{array}{c}219 \pm 24 \\
1 \mathrm{~b}\end{array}$ & $\begin{array}{l}1260 \pm \\
346 \mathrm{a}\end{array}$ & $\begin{array}{l}267 \pm \\
18 ;\end{array}$ & $\begin{array}{c}2652 \pm 17 \\
76 \mathrm{a}\end{array}$ & $\begin{array}{c}2088 \pm 9 \\
43 \mathrm{a}\end{array}$ \\
\hline $\begin{array}{l}\text { Fungal-feeders (ind } \mathrm{kg}^{-1} \\
\text { soil) }\end{array}$ & $\begin{array}{c}775 \pm 29 \\
8 \mathrm{a}\end{array}$ & $\begin{array}{c}106 \pm 83 \\
b\end{array}$ & $\begin{array}{l}1069 \pm \\
759 \mathrm{a}\end{array}$ & $\begin{array}{l}5 \% ? \\
\therefore b\end{array}$ & $\begin{array}{c}705 \pm 638 \\
\mathrm{a} \\
\end{array}$ & $\begin{array}{c}353 \pm 17 \\
7 \mathrm{a} \\
\end{array}$ \\
\hline Omn+Carn (ind $\mathrm{kg}^{-1}$ soil) & $\begin{array}{c}484 \pm 25 \\
7 \mathrm{~b}\end{array}$ & $\begin{array}{c}661 \pm 88 \\
1 \mathrm{ab}\end{array}$ & $\begin{array}{l}1068 \pm \\
329\end{array}$ & $\begin{array}{c}9=16 \\
c\end{array}$ & $\begin{array}{c}465 \pm 291 \\
b\end{array}$ & $\begin{array}{c}885 \pm 32 \\
6 \mathrm{ab}\end{array}$ \\
\hline $\begin{array}{l}\text { Total free-living (ind } \mathrm{kg}^{-1} \\
\text { soil) }\end{array}$ & $\begin{array}{c}2955 \pm 1 \\
290 \mathrm{a}\end{array}$ & $\begin{array}{l}986 \pm 11 \\
63 \mathrm{~b}\end{array}$ & $\begin{array}{l}33,0 . \\
1,7 \mathrm{a}\end{array}$ & $\begin{array}{l}332 \pm \\
22 \mathrm{~b}\end{array}$ & $\begin{array}{l}3822 \pm 16 \\
80 \mathrm{a}\end{array}$ & $\begin{array}{c}3326 \pm 1 \\
245 \mathrm{a}\end{array}$ \\
\hline $\begin{array}{l}\text { Plant-feeders ( } \text { ind } \mathrm{kg}^{-1} \\
\text { soil) }\end{array}$ & $\begin{array}{l}2519 \pm 1 \\
343 \mathrm{bc}\end{array}$ & $\begin{array}{c}6978 \pm 3 \\
679 \mathrm{a}\end{array}$ & $\begin{array}{l}3.12 \pm \\
997 \mathrm{~b}\end{array}$ & $\begin{array}{c}95 \pm 7 \\
0 \mathrm{~d}\end{array}$ & $\begin{array}{c}1150 \pm 85 \\
7 \mathrm{c}\end{array}$ & $\begin{array}{l}4201 \pm 1 \\
960 \mathrm{ab}\end{array}$ \\
\hline Enrichment Index (EI) & $72 \pm 9 \mathrm{a}$ & $\overline{71 \pm 2^{1}} \overline{\mathrm{a}}$ & $\bar{b} 6 \pm 14$ & $\begin{array}{c}24 \pm 2 \\
5 \mathrm{~b}\end{array}$ & $31 \pm 14 b$ & $\begin{array}{c}52 \pm 18 \\
\mathrm{ab}\end{array}$ \\
\hline Basal Index (BI) & $16 \pm 3 b$ & $\overline{\mathrm{C}} 4 \mathrm{c}$ & $18 \pm 9 \mathrm{~b}$ & $\begin{array}{c}70 \pm 2 \\
9 \mathrm{a}\end{array}$ & $\begin{array}{c}43 \pm 29 \\
\mathrm{ab}\end{array}$ & $15 \pm 4 b$ \\
\hline Structure Index (SI) & $69 \pm 5 \mathrm{c}$ & $3 \pm 5 a$ & $\begin{array}{c}78 \pm 12 \\
\text { abc }\end{array}$ & $\begin{array}{c}13 \pm 2 \\
1 \mathrm{~d}\end{array}$ & $\begin{array}{c}48 \pm 33 \\
\text { bcd }\end{array}$ & $81 \pm 5 b$ \\
\hline $\begin{array}{l}\text { Nematodes Channel } \\
\text { Ratio (NCR) }\end{array}$ & $67 \pm$ オ & $\begin{array}{c}68 \pm 19 \\
a b c\end{array}$ & $\begin{array}{c}58 \pm 18 \\
\text { bc }\end{array}$ & $\begin{array}{c}87 \pm 1 \\
5 \mathrm{ab}\end{array}$ & $\begin{array}{c}74 \pm 24 \\
\mathrm{abc}\end{array}$ & $85 \pm 7$ a \\
\hline Genera Richness & $12 \therefore 1 b$ & $8 \pm 4 b c$ & $9 \pm 1 \mathrm{c}$ & $3 \pm 2 d$ & $\begin{array}{c}12 \pm 4 \\
\text { abc }\end{array}$ & $16 \pm 2 \mathrm{a}$ \\
\hline Shannon Index & $2.02 \pm 0$ & $\begin{array}{l}1.69 \pm 0 . \\
51 \mathrm{~b}\end{array}$ & $\begin{array}{l}1.88 \pm 0 \\
.09 \mathrm{~b}\end{array}$ & $\begin{array}{c}0.68 \pm \\
0.47 \\
c\end{array}$ & $\begin{array}{c}1.55 \pm 0.7 \\
3 \mathrm{abc}\end{array}$ & $\begin{array}{l}2.31 \pm 0 . \\
11 \mathrm{a}\end{array}$ \\
\hline
\end{tabular}

Significant differences were tested by GLS followed by Tukey HSD post hoc tests and bear different letters for P-values $<0.05$. 


\section{Declaration of competing interests}

$\bigotimes$ The authors declare that they have no known competing financial interests or personal relationships that could have appeared to influence the work reported in this paper.

$\square$ The authors declare the following financial interests/personal relationships which may be considered as potential competing interests: 
Credit Author Statemenet

Marie Sauvadet - Investigation, Formal analysis, Software, Writing - Original draft, Writing - Review \& Editing

Jean Trap - Methodology, Investigation, Formal analysis, Software, Writing - Review \& Editing

Gaëlle Damour - Formal analysis, Writing - Review \& Editing

Claude Plassard - Methodology, Formal analysis, Writing - Review \& Editing

Karel Van den Meersche - Resources, Methodology, Formal analysis, Investigation, Writing

- Review \& Editing

Raphaël Achard - Resources, Methodology, Investigation, Wr..ㄱ․ ‥ Review \& Editing

Clémentine Allinne - Resources, Methodology, Writing - ke view \& Editing

Patrice Autfray - Methodology, Investigation, Writing - `eview \& Editing

Isabelle Bertrand - Writing - Review \& Editing

Eric Blanchart - Methodology, Investigation, W i.n ; - Review \& Editing

Péninna Deberdt - Resources, Methodolr gy. Wrııing - Review \& Editing

Séguy Enock - Investigation, Writing - Revitw \& Editing

Jean-Daniel Essobo - Investigation, Wn ing - Review \& Editing

Grégoire T. Freschet - Writing - ? eview \& Editing

Mickaël Hedde - Software, Fo nal analysis, Writing - Review \& Editing

Elias de Melo Virginio F lho - Methodology, Investigation, Writing - Review \& Editing

Bodovololona Rabary - N ethodology, Investigation, Writing - Review \& Editing

Miora Rakotoarivelo -Investigation, Writing - Review \& Editing

Richard Randriamanantsoa - Methodology, Investigation, Writing - Review \& Editing

Béatrice Rhino - Resources, Methodology, Writing - Review \& Editing

Aude Ripoche - Resources, Methodology, Investigation, Formal analysis, Writing - Review \& Editing

Elisabeth Rosalie - Investigation, Writing - Review \& Editing

Stéphane Saj - Methodology, Formal analysis, Writing - Review \& Editing 
Thierry Becquer - Resources, Supervision, Project administration, Funding acquisition, Methodology, Formal analysis, Writing - Review \& Editing

Philippe Tixier - Resources, Supervision, Project administration, Funding acquisition, Methodology, Software, Formal analysis, Writing - Review \& Editing

Jean-Michel Harmand - Resources, Supervision, Project administration, Funding acquisition, Methodology, Investigation, Formal analysis, Writing - Review \& Editing 
Graphical abstract

Agroecosystem plant diversification on two types of weathered tropical soils

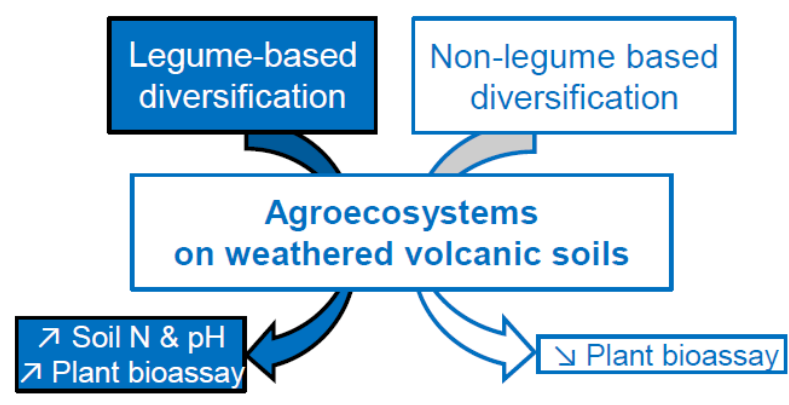

Desired plant community trait:

High $\mathbf{N}$ concentration

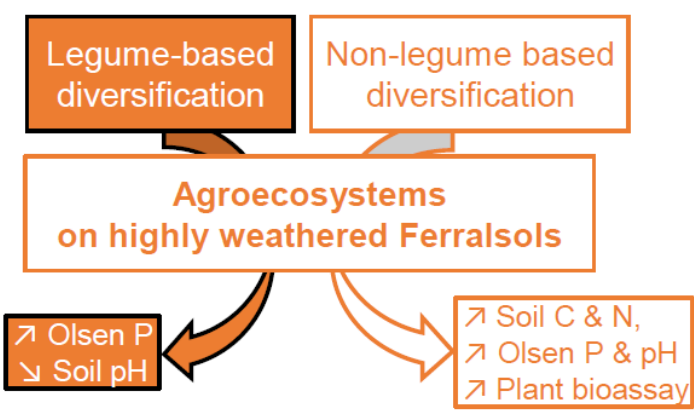

Desire ' Jlant community trait: Hinh 1 - concentration 


\section{Highlights}

- We compared plant diversification impacts on soil fertility across 6 agroecosystems

- Benefits of plant diversification depended on both legume presence and soil type

- Legume-based diversification was mostly beneficial on the younger soils

- Ferralsols' fertility was improved with plant communities' litter P content

- Plant communities' traits were linked with diversification impacts on contrasting soils 